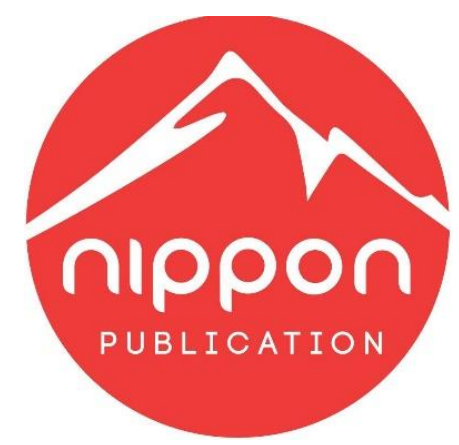

\title{
Review
}

\section{Phytoremediation: green technology for improving aquatic and terrestrial environments}

\author{
Hossein Farraji ${ }^{1, *}$, Brett Robinson ${ }^{1}$, Parsa Mohajeri ${ }^{2}$, Tayebeh Abedi ${ }^{3}$ \\ ${ }^{1}$ School of Physical and Chemical Sciences, University of Canterbury, New Zealand \\ ${ }^{2}$ Department of Soil and Physical Sciences, Lincoln University, New Zealand \\ ${ }^{3}$ Umea Plant Science Centre, Department of Forest Genetics and Plant Physiology, Swedish University of Agricultural Sciences \\ (SLU), 90183 Umea, Sweden
}

\author{
*Corresponding Author: Hossein.farraji@ canterbury.ac.nz
}

Received 12 February 2020; Accepted 16 March 2020

\begin{abstract}
Environmental remediation by traditional physicochemical methods has several drawbacks, the most important of which is the high cost. Phytoremediation is the use of plants and associated microorganisms to improve degraded environments, Plant sensitivity to climate, seasonal growing, resistant to toxic compounds and suspended solids are limitations of this cost effective technology. Costs of phytoremediation can be offset by the production of valuable biomass for timber, fuel, essential oils and other uses. In some cases, the biomass may contain high concentrations of valuable trace elements such as nickel. Successful phytoremediation depends on suitable plants selection and application of appropriate agronomic techniques. In most cases, locally native plants are the most suitable phytoremediator for phytoremediation. This review collected 20 phytoremediation related terms containing phytomining, agromining, phytoextraction, phytostabilization, rhizoremediation, phytodegradation, rhizodegradation, phytovolatilization, phytopumping, phytotransformation, phytofiltration, rhizofiltration, phycoremediation, dendroremediation, cyanoremediation, mycoremediation, phytosequestration, phytoimmobilization, phytoaccumulation, phytostimulation, and phytodesalination. More than 200 research article reviewed for this paper.
\end{abstract}

Keywords: Biodegradable, Mechanism, hyperaccumulator, Sustainable protection of environment

\section{INTRODUCTION}

Environmental degradation may arise through both natural and anthropogenic processes (Tarzia et al., 2002). Overpopulation and waste management are two sides of industrialization (Farraji et al., 2016) which is clear indicator for necessity of environmental improvement.

Physicochemical technologies for the decontamination of polluted sites include chemical precipitation, membrane filtration, adsorption, coagulation-flocculation, Photocatalytic degradation, ion exchange, oxidation with ozone, oxidation with hydrogen peroxide, flotation and electrochemical methods (Fu and Wang, 2011) are high cost and cannot be used as a single process to achieve environmental standards (Ahmaruzzaman, 2011). Cost effective, ecofriendly green technology is urgently required for improving degraded environments. These remediation methods should be fundamentally sustainable treatment technologies for gaining suitable environmentally sound goals.

Phytoremediation is the use of plants to improve degraded environments (Robinson et al., 2003). Phytoremediation can be divided into specific mechanisms, including phytostabilization, phytoextraction, phytovolatilization, phytoevaporation, phytodegradation, phytodesalination, rhizofiltration and rhizodegradation (Awa and Hadibarata, 2020). These subsets are divided based on the goal of phytoremediation, the media in which phytoremediation occurs and the types of contaminants that are present. Phytoremediation is invariably a slow treatment method compared to other (Weatherford et al., 1997) which was presented in the early years of phytoremediation technology appearance stated that only 75 polluted sites from all 1300 national contaminated sites in US were decontaminated through the 15 years. Nowadays, numerous of advanced techniques added as new subsets for this green technology and additional augmentation and amendment are suitably applied for high-efficiency environmental cleaning even with $100 \%$ pollutant removal in a short time (Gangola et al., 2015). 
Plant selection is a critical success factor for phytoremediation. High biomass plant species with high tolerance to elevated concentrations of several contaminants are often desirable characterists. The most suitable plant species may often be found colonizing polluted areas (Farraji, 2014; Farraji et al., 2016; Robinson et al., 1999), such as plants growing in abandoned mine sites. Species such as phyllanthus balgooyi, which is a Nickel hyperaccumulator (Van der Ent et al., 2013b) and Phytolacca acinosa Roxb growing in manganese tailings (Xue et al., 2004). Alternatively, native vegetation or even crop plants may be established on contaminated sites, potentially with the judicious use of soil conditioners.

Suitable plant selection for phytoremediation extremely depends on the nature of the contaminants and their concentrations (Pilon-Smits, 2005), age of the site (Hutchinson et al., 2001), depth (Cunningham et al., 1996) volatilization rate (Ghosh \& Singh, 2005) and biodegradability (Joner \& Leyval, 2003). Furthermore, the selection of a suitable green technology for specific pollution is essential for effective phytoremediation. For example, inorganic pollution could be treated by phytostabilization, phytovolatilization and rhizoremediation methods (Cunningham et al., 1996; Nwoko, 2013) based on their physicochemical characteristics and concentration as well as their biodegradability.

Phytoremediation process can be enhanced through soil conditioners, such as compost (Mangkoedihardjo, et al., 2008), cow dung (Essien et al., 2015; Njoku et al., 2012), olive waste (Nogales and Benítez, 2006), rhizobacteria (Gurska et al., 2009; Langella et al., 2014), biochar (Houben et al., 2013), adsorbent (Mojiri et al., 2016), and plant growth promoters (Vamerali, 2011). The main target of this review is to present different merit aspects of phytoremediation as green technology and their eligibility for environmental cleaning.

\section{PHYTOREMEDIATION: TYPES AND RELATED DEFINITION}

There are several types of phytoremediation methods, mechanisms, techniques, and related definitions which frequently cited in literatures. Alkorta and Garbisu, (2001) divided phytoremediation to 2 main types. Cluis, (2004) classified 4 types of phytoremediation for soil decontamination. Vishnoi and Srivastava, (2007) explained 6 types of phytoremediation. Bora and Sarma, (2020) explained 7 types of phytoremediation based on the types of plant, condition of site, and characteristics of contaminants. In this review the main types of phytoremediation techniques, mechanisms of phytoremediation, equal definition for a specific remediation in literatures, bacteria, algae, and fungi based phytoremediation as well as traditional definition for phytoremediation explained.

\subsection{Rhizoremediation}

Plants release sugar, amino acids and alcohols into the rhizosphere, which form a substrate for the growth of bacteria and fungi (Mishra and Arora, 2019). These microorganisms can be selected to degrade specific soil contaminants. Several amendments and augmentation techniques can enhance the efficiency of this treatment method, including enzymes (Chen et al., 2016) organic matter (Baudoin et al., 2003), plant growth promoters (Ganesan, 2008) and biosurfactants (Khatisashvili et al., 2015) have been used. Rhizoremediation can treat a wide range of pollutants including the immobilization of metallic elements (Chien et al., 2015; Wang et al., 2013), PAHs (Bisht et al., 2014; Feng et al., 2014), Polychlorinated biphenyl (Pino et al., 2016), petroleum (Akhundova and Atakishiyeva, 2015; Mohsenzadeh et al., 2010), herbicide (Zhu et al., 2012). This type of phytoremediation is going to be a major part of phytoremediation and nowadays have high concerning by scientists and research groups for both biodegradable and non-biodegradable pollutants. Rhizoremediation could be an advanced compact combination of phytoextraction, phytovolatilization, phytotransformation and phytostabilization (Farraji et al., 2017).

\subsection{Rhizodegradation}

This phytotreatment method is also known as phytostimulation (Souza et al., 2013). Rhizodegradation normally applies for terrestrial media and defined as bioremediation / degradation of organic contaminants (hydrocarbons) in the rhizosphere area with the assistance of microbial communities. Plant-microbial interaction plays a critical role in the efficiency of this treatment method. Microorganisms in the plant rhizosphere can break down hazardous organic contaminants, such as herbicides (Lin et al., 2011), perchlorate (Yifru and Nzengung, 2008), crude oil (Unterbrunner et al., 2007), Polyhydroxy aromatic compounds (Lu et al., 2011), and diesel (Kaimi et al., 2007) to harmless and /or nontoxic products. Sugar, amino acid and alcohols are released by plant roots and microbial communities use these energy and food sources for consuming and digesting organic pollutants. This method is a highly rapid treatment system in comparing with phytodegradation because of microbial community association. The biostimulation of microbial activities in the rhizosphere of phytoremediator plant species can accelerate the degradation of several xenobiotic compounds (Arshad et al., 2007). 


\subsection{Phytovolatilization}

Phytovolatilization which is also known as phytopumping highly depends on physical properties of pollutants. The, polarity, solubility and hydrophobicity should be contained in target pollutants. Readily soluble in water and volatile organic compound could be treated by this type of phytoremediation technique. Phytovoaltilization can be used for heavy metals (As, Se and Hg), BTEX, MTBE, TCE, vinyl chloride, carbon tetrachloride, 1,4-dioxane (Dhillon et al., 2010; Edwards et al., 2011; Heaton et al., 1998; Sakakibara et al., 2010). Limitation and drawbacks of phytovolatilization can be summarized thus:

- The pollutants should be soluble to uptake by plant roots

- Transferring to leaves should be done properly

- Converting to volatile form in the plant tissues

- Volatilize to atmosphere in final process

1. Hyperaccumulator or genetically modified plants have the greatest potential for phytovolatilisation (Meagher and Heaton, 2005). Following tips are essential for phytovolatalisation(Chen et al., 2017, Di et al., 2019,.

2. Plant tolerance to high concentration of toxic pollutants

3. Ability of plant for altering their rhizosphere for higher uptake essential and toxic elements

4. Availability of endogenous transporters in hairy roots

5. Electrochemical capability of elemental pollutants for increasing upward mobility in plant

6. Strong xylem for transporting essential nutrients from roots to leaves

7. Capability of aboveground parts of plant in electrochemical and chemical controlling pollutants

8. Suitable chemical sink to enhancing essential elements ( $\mathrm{Fe}, \mathrm{Zn}, \mathrm{Cu}$, sulfate and phosphate) storage

9. Suitable physical sink to limited pollutants in high concentration in aboveground tissues

Heavy metals are non-degradable pollutants and phytoremediation techniques for these hazardous materials are limited to phytoextraction and phytomining. Heavy metal phytovolatilization may be investigated for $\mathrm{As}, \mathrm{Hg}$, and $\mathrm{Se}$ which can exist as gases in the natural environment. The toxic nature of gaseous $\mathrm{Hg}$ and $\mathrm{Se}$ is a serious drawback when considering phytovolatilisation.

\subsubsection{Arsenic}

The first report of arsenic hyperaccumulator plant species, Pteris vittata (Ma et al., 2001) opened new opportunities to remove this toxic element from soil. All As hyperaccumulators reported to date are ferns, except for Pityrogramma calomelanos, ferns ( Pteris ) (Chakrabarty, 2015). After extracting arsenic from contaminated soil and accumulating it in stems and frond, toxic element laden biomass is another environmental problem. Thus, finding plant with ability to absorb this metals from soil, degraded to gaseous species by biological converting and finally releasing this gaseous metallic elements to atmosphere is the major foundation of phytovolatilization of arsenic. Nevertheless, finding suitable plants for these issues are quite hard and transgenic plants could increase or add ligands to make hosted plants eligible for phytovolatilization. Pteris vittata is a capable arsenic hyperaccumulator since of following specification:

1. Extremely high tolerance to arsenic $>1 \%$ dry weight

2. Remarkable biomass production, especially root exudates

3. High translocation index

4. High ability in reduction As (V) to As (III)

5. Capability to keep phosphorus in high concentration (Ma et al., 2001)

6. Capability to releasing arsenic from secretory glands of the fronds (Hokura et al., 2006)

7. As detoxification is consequence of enzymatic and non-enzymatic antioxidants (Cao et al., 2004)

8. Gametophytes of $p$. vittata can grow in high concentration of arsenic (Gumaelius et al., 2004)

9. Ability to volatilization of $90 \%$ arsenic uptake (Sakakibara et al., 2010)

10. Eligible for enhancing As volatilization by organic amendment (Dhillon et al., 2010)

\subsubsection{Mercury}

This element has the ability to form very strong covalent bonds with sulfur groups in terrestrial media consequently mobility of mercury from laden (contaminated or natural) land and sediments (Krabbenhoft and Babiarz, 1992; Wallschläger et al., 1996). Humic substances also could be the target of forming strong bonds by mercury elements and finally stabilizing $\mathrm{Hg}^{2+}$ in the atmosphere. Aquatic media are suitable for $\mathrm{Hg}^{2+}$ reduction to $\mathrm{Hg}(0)$. Genetically modified Arabidopsis thaliana and Nicotiana tabacum contain can reduce $\mathrm{Hg}$ by gene than convert $\mathrm{Hg}$ (II) to $\mathrm{Hg}(0)$, 
which is the less toxic metallic mercury and it can easily volatilize to the atmosphere (Meagher, 2000). Plants which engineered by modified bacterial mercuric reductase gene, merA, could be considered as suitable to remove available inorganic mercury and methylmercury from contaminated terrestrial and sediments. Arabidopsis thaliana and Nicotiana tabacum are two traditional plant species which capable for the genetic engineering process (Heaton et al., 1998). Liriodendron tulipifera tissue was cultured and assisted by merA gene to construct the reduction of toxic ionic mercury, $\mathrm{Hg}$ (II) to elemental mercury, $\mathrm{Hg}(0)$. Gen transformed plantlet germinate and grew well in mercurycontaminated land and these plantlets could release mercury 10 times more than the control (untransformed) (Rugh et al., 1998). Mercury removal from aquatic media also could be planned by combining phytoremediation methods, such as phytofiltration and phytovolatilization to reach higher efficiency in pollutant removal. Moreno et al. (2008) method causes $95 \%$ removal by Brassica juncea $\mathrm{L}$.

\subsubsection{Selenium}

Phytovolatilization is a term for the volatilization of $\mathrm{Se}, \mathrm{Hg}$ and As with plant species. Phytoremediation first coined by Raskin in 1994 and related "phyto" techniques used based on the main mechanism of removal. Furthermore, based on the our best computer navigation science, the first article which used phytovolatilization belongs to Terry et al. (1995). Nevertheless, the historical background of selenium volatilization by plants belongs to Lewis et al. (1966), which used Astragalus racemosus as accumulator plant species and Medicago sativa as non-accumulator plant species. The final report of that study indicates that; plant foliage is the main volatilization part and the rate of Se volatilization has a high correlation with daytime. Comparing accumulator and non-accumulator plant for selenium volatilization were recently investigated by Statwick et al. (2016). Volatilization of selenium is highly depended on soil microbial communities. Based on the report of Chau et al. (1976) and Reamer and Zoller (1980), sterilization of soil by steam causes elimination of microbial activities, consequently, Se volatilization totally will be stopped. Higher recorded volume of volatilization of Se was during spring compared with the same period in winter, which is reported by McDonald \& Duncan. (1979) is another confirmation for microbial basement of volatilization, which normally is very high in spring and extremely decrease in winter. Furthermore, volume of volatilized Se have linear correlation with volume of water-soluble selenium in soil (Abu et al., 1968; Zieve \& Peterson, 1981). Agrostis tenuis showed linear correlation in volatilization of selenium with time as variable factor. The presence and concentration of Se in soil are major factors in volume and the mechanism of volatilization. In high concentration or the rise of Se, accumulation of this element will carry out in the root by ion exchange mechanism. Meanwhile, low concentration or increasing rate of selenium known as uptake.

\subsection{Phytotransformation}

This phytotreatment method is also known as phytodegradation. In this environmental cleaning method which is only applicable for degradable pollutants, pollutants uptake by plant and their breaking down process to nonhazardous material carried out in plant body through the metabolic process. Organic compounds such as petroleum (De-Farias et al., 2009; Park et al., 2011) by Helianthus annuus, Brassica campestis, Festuca arundinacea, pesticide (Schwitzguébel et al., 2006), dye (Kagalkar et al., 2011) by Blumeam alcolmii, TNT (Das et al., 2012) by Chrysopogon zizanioides had been treated by phytodegradation. This green technology which is based on herbal phytoremediator plant species highly suffers from long treatment time. This causes an increase in environmental risk of pollutants among the long period of decontamination time.

This technique is also based on the plant (hairy roots) ability of degradation or transformation of pollutants inside or outside of plant tissues by the compounds which normally produce by plants such as enzymes. In case of outside transformation of pollutants, the required compounds for degradation are released from plant roots. The target pollutants for this treatment method should be degradable and, usually, organic compounds are set as an objective of decontamination. Previous researchers illustrate that this technique enrolled enzymes through the phytotransformation are the peroxidase, cytochromes, and laccases, which followed by their conjugation with glutathione, glucose or peptides in vacuole and /or cell wall apoplast. Primary studies concentrated on aquatic plant species (Adler et al., 1994). Meanwhile, in vitro cell, tissue culture (Suresh et al., 2005) was used in recent research. Transgenic plant for enhancing degradation efficiency (Alderete et al., 2009), hairy roots as metabolizer of toxic compounds pathway common metabolic system in aquatic media and the presence of $\mathrm{H}_{2} \mathrm{O}_{2}$ for xenobiotic stress protection (Singh et al., 2006) are used through the phytotransformation research process. Most of related studies to phytodegradation concentrate on phenol removal. Nevertheless, wide range of pollutants has been demonstrated by previous investigation on PCB (Rezek et al., 2008), TNT (Hughes et al., 1996) and DDT by phytodegradation technique.

Phytodegradation had been improved from lab scale studies for the past decades and pilot studies (Alderete et al., 2012) for phenol removal are going to improve it as an eligible commercial treatment method in the future. In many 
cases, detoxification of pollutants is controlled by oxidoreductive enzymes (peroxidases), which are exuded in high volume by plants in response to water pollutants, and environmental chemical stress. These abundant isoenzymes mainly localized in vacuoles and cell walls (Coniglio et al., 2008). Plant species with the ability to produce hairy roots and suitable enzyme plays a main role in degradation of pollutants and several species have been investigated in literatures (Table 1). Furthermore, new plants such as garlic (Wang et al., 2015) and belladonna (Mazaheri and Piri, 2015) are cases of most recent studies. In a nutshell, focusing on optimization metabolisms and pollutants is one side of the future improvements in phytodegradation technique and the enhancement of pollutants uptake and degradation capacity is the other side of this precious green technology (Agostini et al., 2013).

\subsection{Phytofiltration}

In aquatic media as major and critical part of polluted environment, phytoremediation is known as the term of phytofiltration (rhizofiltration), which is an advanced plant base remediation for soluble pollutants. In other words, plants application for contaminant removal from aquatic media (water and aqueous waste streams). This attractive technique could be classified as following tips:

1. Rhizofiltration in hydroponically growing plant roots

2. Bioadsorbent based methods

3. Lagoons and constructed wetlands

As a non-conventional types of phytoremediation for wastewater treatment, phytofiltration is a capable aquatic treatment. Multiple related advantages of this environmentally sound treatment alternative caused it to gain interest nowadays (Olguí, 2003; Olguín and Sánchez, 2010). Aquatic plant species (floating, emergent or submerged) with their hairy roots (in most cases) or fronds (only aquatic ferns) do the removal process. This technique could be challenged in are such as, air waste (CO2), aquatic media nutrients and xenobiotic of wastewater. The main involved parts through the treatment process are roots, stems, leaves (fronds), water column and microbial communities biomass (Olguín \& Sánchez, 2012). There are some challenges on removal efficiency by phytofiltration method, especially in the case of heavy metal adsorption in a natural environment. Lu et al. (2011) selected two ponds with total area $7500 \mathrm{~m}^{2}$ and covered $1 / 20$ total area with water lettuce. They collected 135 samples and analyzed $\mathrm{Cr}, \mathrm{Mn}$, $\mathrm{Co}, \mathrm{Pb}, \mathrm{Cd}, \mathrm{Fe}, \mathrm{Zn}, \mathrm{Al}, \mathrm{Ni}, \mathrm{Cu}, \mathrm{K}, \mathrm{Ca}, \mathrm{Mg}$ and $\mathrm{Na}$. Their results indicate that pollutant removal in natural environment is far different with the laboratory researches in controlled conditions. Anyway, in comparing with traditional treatment such as adsorption, photocatalytic degradation, chemical precipitation, coagulation-flocculation hydrogen peroxide and ozone oxidation or electrochemical methods (Kurniawan et al., 2006), which are not only high cost and faced on with disposal problem, but also could not achieve the desired or acceptable results as water quality, Phytofiltration, even with low efficiency in natural condition, is a cost effective environmentally sound green method for waste management. In case of toxic metal (currently known as metallic elements), it is a suitable treatment method. Aquatic phytoremediation as an eco-friendly plant base treatment is the same as Mother Nature; sustainable, trustable and without switching a problem to another environmental problem (Farraji, 2018). Biosorbent-base system, natural/constructed wetlands, rhizofiltration systems, lagoons, hydroponic plant base treatment could be classified as phytofiltration (Olguín and Sánchez, 2010; Sánchez and Olguín, 2009), which often are short time treatment methods. Figure 1 illustrates classification of phytofiltration systems with aquatic plants. And Table 1 shows numerous of recent phytofiltration studies.

Type of flow

Type of Plants

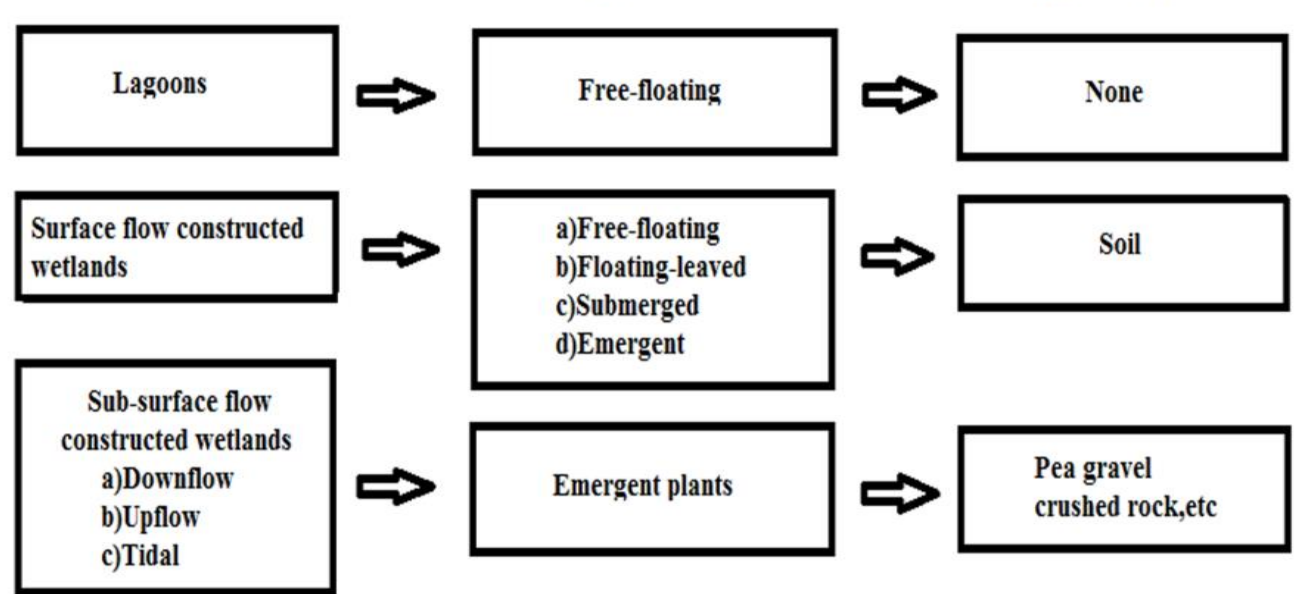

Figure 1. Classification of phytofiltration systems (Olguín and Sánchez, 2010) 
Farraji et al.

Phytoremediation: green technology for improving aquatic and terrestrial environments

Table 1. Phytofiltration of pollutants as short time phytoremediation technology

\begin{tabular}{|c|c|c|c|c|c|}
\hline Plant/s & $\begin{array}{l}\text { Pollu } \\
\text { tion/s }\end{array}$ & Time & $\begin{array}{l}\text { Untreated } \\
\text { concentration }\end{array}$ & Removal \% & Reference \\
\hline \multirow[t]{2}{*}{ Helianthus annuus L. } & $\mathrm{U}$ & \multirow{2}{*}{$\begin{array}{l}2 \\
\text { days }\end{array}$} & $2.5 \times 10^{-4} \mathrm{~g} \mathrm{U}$ & $50 \%$ & \multirow{2}{*}{$\begin{array}{l}\text { (Tomé et } \\
\text { al., 2008) }\end{array}$} \\
\hline & $\mathrm{Ra}$ & & $1.1 \times 10^{-10} \mathrm{~g}$ & $70 \%$ & \\
\hline Limnocharis flava $\mathrm{L}$. & $\mathrm{Cd}$ & $\begin{array}{l}3-30 \\
\text { day }\end{array}$ & $0.5-4 \mathrm{mg} / \mathrm{L}$ & $93 \%$ in low level & $\begin{array}{l}\text { (Abhilash et } \\
\text { al., 2009) }\end{array}$ \\
\hline Brassica juncea $\mathrm{L}$. & $\mathrm{Hg}$ & 5 day & $0-10 \mathrm{mg} / \mathrm{L}$ & $95 \%$ & $\begin{array}{l}\text { (Moreno et } \\
\text { al., 2008) }\end{array}$ \\
\hline Spirodela polyrhiza & As & $72 \mathrm{~h}$ & $190 \mathrm{ng} / \mathrm{mL}$ & 41 & $\begin{array}{l}\text { (Zhang et } \\
\text { al., 2011) }\end{array}$ \\
\hline Pistia stratiotes & $\begin{array}{l}\text { Heav } \\
\text { y } \\
\text { metal } \\
\text { s }\end{array}$ & $\begin{array}{l}60 \\
\text { days }\end{array}$ & $44-0.0053 \mathrm{mg} / \mathrm{L}$ & 20 & $\begin{array}{l}\text { (Lu et al., } \\
2011)\end{array}$ \\
\hline Carex pendula & $\mathrm{Pb}$ & 2 week & $0-10 \mathrm{mg} / \mathrm{L}$ & $1600 \mathrm{mg} / \mathrm{kg}$ & $\begin{array}{l}\text { (Yadav et } \\
\text { al., 2011) }\end{array}$ \\
\hline Hydrilla verticillata & As & $\begin{array}{l}45 \\
\text { days }\end{array}$ & $1500 \mu \mathrm{g} / \mathrm{L}$ & $72 \%$ in field & $\begin{array}{l}\text { (Srivastava, } \\
\text { 2011) }\end{array}$ \\
\hline $\begin{array}{l}\text { Pistia stratiotes } \mathrm{L} \text {. } \\
\text { Salvinia auriculata }\end{array}$ & $\mathrm{Cd}$ & 2 week & $3.5-10.5 \mathrm{mg} / \mathrm{L}$ & $\begin{array}{l}624-3923 \\
\mathrm{mg} / \mathrm{kg}\end{array}$ & $\begin{array}{l}\text { (Veselý et } \\
\text { al., 2011) }\end{array}$ \\
\hline $\begin{array}{l}\text { Salvinia minima } \\
\text { Azolla filiculoides }\end{array}$ & $\mathrm{Pb}$ & 2 week & $25-125 \mathrm{mg} / \mathrm{L}$ & $3867-42862 \mathrm{mg} / \mathrm{kg}$ & \\
\hline Micranthemum umbrosum & $\begin{array}{l}\mathrm{As} \\
\mathrm{Cd}\end{array}$ & $\begin{array}{l}7 \\
\text { days }\end{array}$ & $\begin{array}{l}\text { As: } 1.0 \mu \mathrm{g} / \mathrm{L} \\
\mathrm{Cd}: 30.0 \mu \mathrm{g} / \mathrm{L}\end{array}$ & $\begin{array}{l}\text { AS: } 89.5 \% \\
\text { Cd: } 73.1 \%\end{array}$ & $\begin{array}{l}\text { (Islam et al., } \\
\text { 2013) }\end{array}$ \\
\hline Micranthemum umbrosum & $\begin{array}{l}\text { As } \\
\mathrm{Cd}\end{array}$ & $\begin{array}{l}7 \\
\text { days }\end{array}$ & $\begin{array}{l}\text { As:500 } \mu \mathrm{g} / \mathrm{L} \\
\mathrm{Cd}: 500 \mu \mathrm{g} / \mathrm{L}\end{array}$ & $\begin{array}{l}\text { Uptake pattern: } \\
\text { leaf>stem }>\text { root }\end{array}$ & $\begin{array}{l}\text { (Islam et al., } \\
\text { 2015) }\end{array}$ \\
\hline $\begin{array}{l}\text { Ranunculus trichophyllus } \\
\text { Typha latifolia } \\
\text { Lemnar minor, } \\
\text { Spirodela polyrrhiza, } \\
\text { Myriophyllum spicatum }\end{array}$ & $\begin{array}{l}\mathrm{Pb} \\
\mathrm{Cu}, \\
\mathrm{Zn}\end{array}$ & $\begin{array}{l}\text { Not } \\
\text { given }\end{array}$ & $\begin{array}{l}0.1-13.4 \mu \mathrm{g} / \mathrm{L} \\
0.45-125 \mu \mathrm{g} / \mathrm{L}, 1.00- \\
441 \mu \mathrm{g} / \mathrm{L}\end{array}$ & $\begin{array}{l}\mathrm{Pb} 1104 \mathrm{mg} / \mathrm{kg} \\
\mathrm{Cu} 161 \mathrm{mg} / \mathrm{kg} \\
\mathrm{Zn} 34162 \mathrm{mg} / \mathrm{kg}\end{array}$ & $\begin{array}{l}\text { (Favas et } \\
\text { al., 2016) }\end{array}$ \\
\hline $\begin{array}{l}\text { Eichhornia crassipes } \\
\text { Chlorodesmis } \mathrm{sp} \\
\text { Cladophora } \mathrm{sp}\end{array}$ & $\begin{array}{l}\text { As } \\
\text { COD }\end{array}$ & $\begin{array}{l}15 \\
\text { days }\end{array}$ & As: $6 \mathrm{mg} / \mathrm{L}$ & $\begin{array}{l}\text { COD: } 50-56 \% \\
\text { As: } 20-50 \%\end{array}$ & $\begin{array}{l}\text { (Jasrotia et } \\
\text { al., 2017) }\end{array}$ \\
\hline Pteris vittata & As & $\begin{array}{l}10 \\
\text { days }\end{array}$ & $1000 \mu \mathrm{g} / \mathrm{L}$ & $80 \%$ & $\begin{array}{l}\text { (Huang et } \\
\text { al., 2017) }\end{array}$ \\
\hline Micranthemum umbrosum & As & $\begin{array}{l}\text { One } \\
\text { week }\end{array}$ & $200-750 \mu \mathrm{g} / \mathrm{L}$ & $73-60 \%$ & $\begin{array}{l}\text { (Islam et al., } \\
\text { 2017) }\end{array}$ \\
\hline Warnstorfia fluitans & As & $\begin{array}{l}48-96 \\
\text { hours }\end{array}$ & 5 or $10 \mu \mathrm{M}$ & $\begin{array}{l}\mathrm{pH}: 6.5 \& 9.5 \\
\text { Temperature: } 20 \& \\
30{ }^{\circ} \mathrm{C} \\
\mathrm{O}_{2}: \text { low } \\
\text { concentration }\end{array}$ & $\begin{array}{l}\text { (Sandhi et } \\
\text { al., 2018a) }\end{array}$ \\
\hline Warnstorfia fluitans & As & $\begin{array}{l}\text { One } \\
\text { hour }\end{array}$ & $1 \mu \mathrm{M}$ & $82 \%$ & $\begin{array}{l}\text { (Sandhi et } \\
\text { al., 2018b) }\end{array}$ \\
\hline Salix spp. & $\begin{array}{l}\mathrm{Mn} \\
\mathrm{Zn} \\
\mathrm{Cu}\end{array}$ & $\begin{array}{l}28 \\
\text { days }\end{array}$ & $\begin{array}{l}\mathrm{Mn} 0.27 \mathrm{mg} / \mathrm{L} \\
\mathrm{Zn} 0.33 \mathrm{mg} / \mathrm{L} \\
\mathrm{Cu} 0.32 \mathrm{mg} / \mathrm{L}\end{array}$ & $\begin{array}{l}\text { Leaves } \\
\mathrm{Mn}>\mathrm{Zn}>\mathrm{Cd} \\
\mathrm{Stems} \\
\mathrm{Zn}>\mathrm{Mn}>\mathrm{Cu} \\
\text { Roots } \\
\mathrm{Cu}>\mathrm{Zn}>\mathrm{Mn}\end{array}$ & $\begin{array}{l}\text { (Yang et al., } \\
\text { 2018) }\end{array}$ \\
\hline Potamogeton pisillus L & $\begin{array}{l}\mathrm{As}^{3+} \\
\mathrm{As}^{5+} \\
\mathrm{Hg}\end{array}$ & $\begin{array}{l}20 \\
\text { days }\end{array}$ & $2 \mathrm{mg} / \mathrm{L}$ & $0.1 \mathrm{mg} / \mathrm{L}$ removal & $\begin{array}{l}\text { (Griboff et } \\
\text { al., 2018) }\end{array}$ \\
\hline Pteris multifida & $\begin{array}{l}\mathrm{Pb} \\
\mathrm{Cd} \\
\mathrm{As}\end{array}$ & $\begin{array}{l}24 \\
\text { days }\end{array}$ & $\begin{array}{l}\mathrm{Pb}: 9.5 \pm 1.2 \mathrm{mg} / \mathrm{L} \\
\mathrm{Cd}: 4.2 \pm 0.1 \mathrm{mg} / \mathrm{L} \\
\mathrm{As}: 6.6 \pm 2.0 \mathrm{mg} / \mathrm{L}\end{array}$ & $\begin{array}{l}90 \% \quad \mathrm{~Pb} \quad 36 \% \mathrm{Cd} \\
50 \% \mathrm{As}\end{array}$ & $\begin{array}{l}\text { (Rahman et } \\
\text { al., 2018) }\end{array}$ \\
\hline $\begin{array}{l}\text { Azolla japonica } \\
\text { Azolla pinnata }\end{array}$ & $\begin{array}{l}\mathrm{Cu} \\
\mathrm{Zn}\end{array}$ & $\begin{array}{l}12 \\
\text { days }\end{array}$ & $\begin{array}{l}\mathrm{Cu}: 7 \mathrm{mg} / \mathrm{L} \\
\mathrm{Zn}: 4 \mathrm{mg} / \mathrm{L}\end{array}$ & $\begin{array}{l}\mathrm{Cu}:>80 \% \\
\mathrm{Zn}:>60 \%\end{array}$ & $\begin{array}{l}\text { (Akhtar et } \\
\text { al., 2019) }\end{array}$ \\
\hline
\end{tabular}


Nipp. J. Environ. Sci., 1(1): 1002

\begin{tabular}{|c|c|c|c|c|c|}
\hline Salix spp. & $\begin{array}{l}\mathrm{Fe} \\
\mathrm{Mn}\end{array}$ & $\begin{array}{l}28 \\
\text { days }\end{array}$ & $\begin{array}{ll}4.19 \mathrm{mg} / \mathrm{L} & \mathrm{Fe} \\
3.00 \mathrm{mg} / \mathrm{L} \mathrm{Mn} & \end{array}$ & $\begin{array}{l}\mathrm{Fe}(84 \%) \\
\mathrm{Mn}(69 \%)\end{array}$ & $\begin{array}{l}\text { (yang et al., } \\
\text { 2019) }\end{array}$ \\
\hline Pistia stratiots & $\mathrm{Cu}$ & 20 & $\mathrm{Cu}: 5-20 \mathrm{mg} / \mathrm{L}$ & $68.75 \%$ removal & $\begin{array}{l}\text { (Niazy, } \\
\text { 2019) }\end{array}$ \\
\hline Monosoleum tenerum & $\begin{array}{l}\mathrm{Zn}, \\
\mathrm{Cu}, \\
\mathrm{Ni}, \\
\mathrm{Mn}, \\
\mathrm{Fe}\end{array}$ & $\begin{array}{l}7-49 \\
\text { days }\end{array}$ & 1,10 , and $100 \mathrm{ppm}$ & $\begin{array}{l}\text { Accumulation } \\
\text { behavior changes by } \\
\text { concentration }\end{array}$ & $\begin{array}{l}\text { (Sut et al., } \\
2020)\end{array}$ \\
\hline
\end{tabular}

\subsection{Phycoremediation}

Phycoremediation is a nonconventional type of phytoremediation, which is environmentally sound treatment method and its advantage as cost effective green environmental cleaning method causes it to gain interest (Olguín and Sánchez-Galván, 2010). Application of macroalgae, microalgae, and cyanobacteria was used for biotransformation or removal of metallic elements from aquatic media (Olguí, 2003; Olguín and Sánchez, 2012). Carbon dioxide of waste air and nutrients of wastewater could be removed or biologically transformed by algae and/or cyanobacteria. Phycoremediation contains highly attraction because of its ability for biomass production or biogas emission (Prajapati, 2013). This type of phytoremediation often applied for nutrient removal from animal wastewater (Olguí, 2003), leather processing effluent treatment plant (Figure 2) (Hanumantha, 2011) which contain high organic pollutants. Heavy metals could be removed by transgenic microalgae (Rajamani et al., 2007), biosorbent augmentation (Dixit and Singh, 2013), chromium by biosorbent (brown color form) of the Kappaphycus alvarezii (Kumar et al., 2007), Cr (VI) in presence of Calcium (Gomes and Asaeda, 2009) and Arsenic by Cladophora algae (Figure 3) (Jasrotia et al., 2014). Microalgae have the capacity to bind its 10\% of biomass to metallic elements. Sequestering hazardous and essential metals, which often compete together is the survival mechanism for algae in polluted waters (Rajamani et al., 2007). Since most of the polluted wastewaters finally discharged to water sources. Marine algae as a high productivity and effective phycoremediator in the final destination of anthropogenic pollutants, could have a critical role in environmental protection.

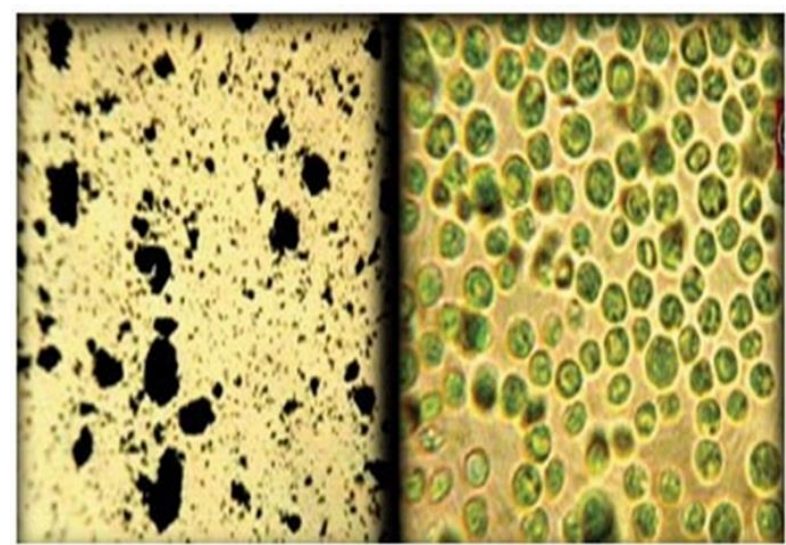

Figure 2. photomicrograph shows leather processing plant effluent dissolved solid before (left) and after (right) phycoremediation by algae (Hanumantha, 2011)
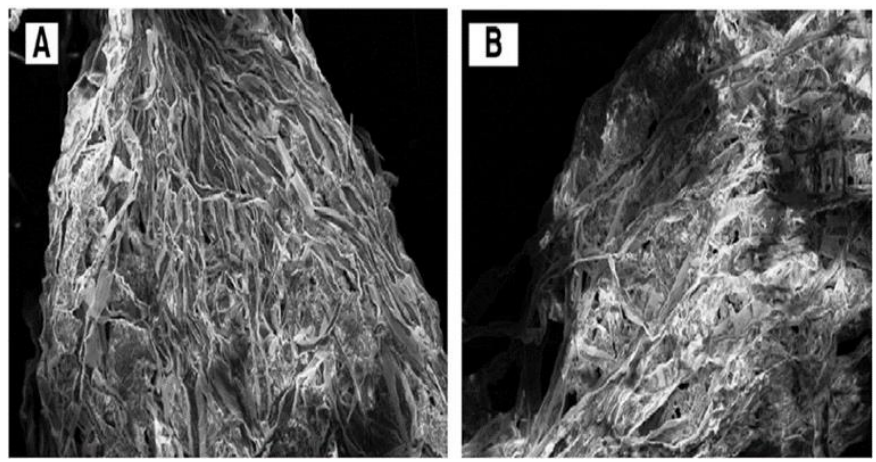

Figure 3. SEM cell surface of Cladophora sp. at $10 \mathrm{kv} 200 \mathrm{X}$, A) control, B) Arsenic treated (Jasrotia et al., 2014) 
Farraji et al.

Phytoremediation: green technology for improving aquatic and terrestrial environments

\subsection{Dendroremediation}

This type of phytoremediation specified as trees application for cleaning process. The most common pollutant that have been treated by dendroremediation is TNT in the abandoned military land areas (Schoenmuth and Pestemer, 2004b). Numerous researchers illustrated the efficiency of dendroremediation for polluted soil by crude oil, landfill leachate, metallic elements (Gonzälez et al., 2008) and municipal wastewater. Huge biomass production of tree species, fast growing, and high degradation capacity of woody tissues is the potentials of dendroremediation and these gigantic phytoremediators (Schoenmuth and Pestemer, 2004a, 2004b) and desirable rural landscape, especially in wildland urban interface (Langholtz et al., 2005) mentioned for dendroremediation by tree plant species. The economic viability of dendroremediation by Eucalyptus grandis have been assessed by optimization model in USA for municipal wastewater treatment and the collected data (considering irrigation, planting and nutrient supply) illustrate that; based on the site productivity and interest rate, for each $\$ 1 \mathrm{~kg}^{-1} \mathrm{~N}$ spent in increasing the dendroremediation services, \$223-376 ha ${ }^{-1}$ was increased in forest land value (Langholtz et al., 2005).

\subsection{Cyanoremediation}

This type of phytoremediation which carried out by tiny plants for wastewater, which is known as cyanobacteria, is rarely common in scientific researches (Gothalwal and Chillara, 2012) and is often specified for wastewater with high concentration of phosphates and nitrates. Meanwhile (Zhao et al., 2015), report $98 \%$ cadmium removal by Nostoc calcicola cyanobacterium in a novel reactor from water furthermore, (Yin et al., 2012) defined cyanoremediation as the use of cyanobacteria to remediate metallic elements. Finally, several bacterial species have been reviewed by (Mani and Kumar, 2014) throughout the cyanoremediation of metallic elements such as $\mathrm{Cr}, \mathrm{Cu}, \mathrm{U}$, $\mathrm{Cd}, \mathrm{As}, \mathrm{Fe}, \mathrm{Mn}, \mathrm{Se}, \mathrm{Zn}, \mathrm{Pb}$ and $\mathrm{Sr}$ in 16 researches carried out between 2008-2013. This kind of phytoremediation also going to receive more concerns in future researches.

\subsection{Mycoremediation}

Fungi as vigorous agent play the main role in the decomposition of abandoned waste matter. In the biosphere, lignin is the second most abundant substrate with organic structures (Šašeket al., 2005). Presence of fungi is recognized as the essential requirement of the soil food chain (Rhodes, 2012) in supplying nourishment for terrestrial macro and microorganisms. Mycelium is the key organism throughout the breaking down the organic compounds. Bioremediation defined as the use of live organisms in order to organic compounds (could be presented as pollutants) degradation. Organic compounds bioremediation by fungi (Singh, 2006), which is recognized as mycoremediation, is a process that the enzyme present in the filamentous fungi bioremediation system properly is utilized for degradation lignin by lignin peroxidase, laccase, manganese peroxidase and $\mathrm{H}_{2} \mathrm{O}_{2}$, thus producing enzyme that could be used for peroxidase purposes similar to lignin compounds. These degradations could be augmented by supplementary carbon sources (straw, sawdust and corn cob) at the polluted areas (Rhodes, 2014) as a cleaning method for earth pollutions. Fungi bioremediation (mycoremediation) could be considered as alter tools for structures of chemical and molecular of toxic compounds to decreasing their negative impact on the environment or converting them to harmless products (Jones, 2009). The highly advanced fungi with recognized bioremediation potentials involved genera Agrocybe for biodegradation of hydrocarbons (Tayung \& Barik, 2011). Meanwhile, four generations among the white rot fungus show massive potential for lignin compounds; these generations are Trametes, Phanerochate, Pleurotus and Bjerkandra (Singh et al., 2011). Schizopora paradoxa is a specific white rot fungi, which has a high tolerant to metallic elements dye, and polycyclic aromatic hydrocarbons which are found in Korea (Min et al., 2015). This finding clearly illustrates that may mycoremediation will present a wide range of opportunity for multi-contaminant polluted areas in future studies. The rapid emerging trend of research on mycoremediation shows that future researchers will concern on this treatment method for new aspects of pollutant. Numbers of mycoremediation as another short time phytoremediation are collected in Table 2.

Table 2. Mycoremediation as one of fast treatment method of pollutant removal

\begin{tabular}{|c|c|c|c|c|}
\hline Fungi species & Pollutant /s & $\begin{array}{l}\text { Time } \\
\text { period }\end{array}$ & $\begin{array}{l}\text { Removal } \\
\text { degradation \% }\end{array}$ & Reference \\
\hline Pleurotus ostreatus & Oxyteracycline & 14 days & 23 & $\begin{array}{l}\text { (Migliore et al., } \\
\text { 2012) }\end{array}$ \\
\hline Mucor hiemalis Wehmer & $\begin{array}{l}\text { Domestic } \\
\text { wastewater } \\
\text { sludge }\end{array}$ & 5 days & $\begin{array}{lc}\text { COD } & 92.6 \\
\text { TSS } & 96 \\
\text { Turbidity } & 99.4\end{array}$ & $\begin{array}{l}\text { (Molla et al., } \\
\text { 2012) }\end{array}$ \\
\hline
\end{tabular}


Nipp. J. Environ. Sci., 1(1): 1002

\begin{tabular}{|c|c|c|c|c|}
\hline $\begin{array}{l}\text { Trichoderma } \\
\text { longibrachiatum }\end{array}$ & Pesticide & 15 days & 85 & $\begin{array}{l}\text { (Gangola et al., } \\
\text { 2015) }\end{array}$ \\
\hline Aspergillus oryzae & & & 81 & \\
\hline $\begin{array}{l}\text { Fusarium oxysporum 8-11P } \\
\text { Fusarium sp.ZZZ1124 }\end{array}$ & $\begin{array}{l}\text { Pesticide } \\
\text { Cypermethrin }\end{array}$ & 5 days & 97 & $\begin{array}{l}\text { (Kaur et al., } \\
2015)\end{array}$ \\
\hline $\begin{array}{l}\text { Botryosphaeria laricina } \\
\text { Aspergillus tamarii }\end{array}$ & $\begin{array}{l}\text { Pesticide } \\
\text { Endosulfan }\end{array}$ & 4.2 day & 50 & $\begin{array}{l}\text { (Gangola et al., } \\
\text { 2015) }\end{array}$ \\
\hline Pleurotus ostreatus & PAH & 56 days & $80.25-92.38$ & $\begin{array}{l}\text { (Okparanma et } \\
\text { al., 2013) }\end{array}$ \\
\hline $\begin{array}{l}\text { Pleurotus ostreatus } \\
\text { Augmented by biochar }\end{array}$ & PAH & 42 days & 100 & $\begin{array}{l}\text { (García et al., } \\
\text { 2015) }\end{array}$ \\
\hline $\begin{array}{l}\text { Pleurotus eryngii } \\
\text { Augmented by tween } 80\end{array}$ & $\begin{array}{l}\text { Manganese } \\
\text { phenanthrene }\end{array}$ & 15 days & $\begin{array}{l}92.17 \\
93.85\end{array}$ & (Wu et al., 2016) \\
\hline $\begin{array}{l}\text { Aspergillus } \\
\text { FNBR_L35 } \\
\text { Fusarium sp. FNBR_B7 } \\
\text { Fusarium sp. FNBR_LK5 } \\
\text { Fusarium sp. FNBR_BA5 } \\
\text { Aspergillus } \\
\text { FNBR_LK1 nidulans } \\
\text { Rhizomucor variabilis sp. } \\
\text { FNBR_B9 } \\
\text { Emericella sp. FNBR_BA5 }\end{array}$ & Arsenic & 21 days & $\begin{array}{l}\text { Bioaccumulated } \\
\mathrm{As}=0.023 \text { to } 0.259 \\
\mathrm{mg} / \mathrm{L} \\
\text { Biovolatilized } \\
\mathrm{As}=0.23 \text { to } 6.4 \\
\mathrm{mg} / \mathrm{kg}\end{array}$ & $\begin{array}{l}\text { (Singh et al., } \\
\text { 2015) }\end{array}$ \\
\hline Oudemansiella radicata & $\begin{array}{l}\text { Cadmium } \\
\text { PAH }\end{array}$ & 10 days & 93.8 & $\begin{array}{l}\text { (Chen et al., } \\
\text { 2015) }\end{array}$ \\
\hline
\end{tabular}

\begin{tabular}{|c|c|c|c|c|}
\hline Coprinus comatus & $\mathrm{Cd}, \mathrm{Cu}$ & 32 days & $\begin{array}{l}\text { 10.83-16.78 ppm } \\
\text { Accumulation }\end{array}$ & $\begin{array}{l}\text { (Dulay et al., } \\
\text { 2015) }\end{array}$ \\
\hline $\begin{array}{l}\text { Aspergillus fumigatus, } \\
\text { Penicillium rubens }\end{array}$ & $\mathrm{Cd}, \mathrm{Cr}$ & 3 days & $\begin{array}{l}\text { Max } 98 \% \text { for } \mathrm{Cd} \\
\text { Max } 69 \% \text { for } \mathrm{Cr}\end{array}$ & $\begin{array}{l}\text { (Khan et al., } \\
\text { 2019) }\end{array}$ \\
\hline $\begin{array}{l}\text { Absidia cylindrospora } \\
\text { Chaetomium atrobrunneum } \\
\text { Coprinellus micaceus }\end{array}$ & $\begin{array}{l}\mathrm{Cd} \\
\mathrm{Cu} \\
\mathrm{Pb}\end{array}$ & 3 days & $\begin{array}{l}45 \% \text { of } \mathrm{Cd} \& \mathrm{~Pb} \\
45 \% \mathrm{Cd}, \mathrm{Cu}, \quad \& \mathrm{~Pb} \\
100 \% \text { of } \mathrm{Pb}\end{array}$ & $\begin{array}{l}\text { (Albert } \\
\text { 2019) }\end{array}$ \\
\hline Ascomycota & $\begin{array}{l}\mathrm{Cr}, \mathrm{Cu} . \mathrm{As}, \mathrm{Fe}, \\
\mathrm{Mn}\end{array}$ & $\begin{array}{l}100 \\
\text { days }\end{array}$ & $\begin{array}{ll}\text { As } 77 \%, & \text { Mn71\% } \\
\text { Cr60\%, } & \text { Cu52\% } \\
\text { Fe 56\% } & \end{array}$ & $\begin{array}{l}\text { (Hassan et al., } \\
2020)\end{array}$ \\
\hline
\end{tabular}

Results of Table 3 illustrate that mycoremediation is a short time treatment for wide range of pollutants with high efficiency of pollutants removal or degradation in comparison with other types of phytoremediation. Based on the reports of recent studies carried out by Gangola et al. (2015) and García et al. (2015), augmentation could enhance the efficiency of pollutants degradation to highest amounts (almost 100\%) throughout the mycoremediation. This type of phytoremediation is in the lab scale preliminarily studies and may require for more researches in the future. Due to rapid degradation and high adaptation by augmentation system, commercializing of this treatment technique will be valuable. 
Farraji et al.

Phytoremediation: green technology for improving aquatic and terrestrial environments

\subsection{Phytosequestration}

One of the suitable environmental cleaning/protection systems is plant based stabilizing (phytoimobilization) pollutants that prevent off-site movement which is often known as phytosequestration. It causes a protection from no polluted lands as well as managing pollutions in an intensive limited area. This kind of phytoremediation could be carried out by terrestrial plant species for decontamination of soil. In a phytoremediation review paper (Reichenauer and Germida, 2008), phytosequestration is categorized as a type of phytoextraction as well as phytoaccumulation and phytoabsorption. Assimilation of atmospheric $\mathrm{CO}_{2}$ by photosynthetic pathway in land plants for sequestration of terrestrial carbon is reported by Jansson et al. (2010) and heavy metal removal with phytosequestration is reported by Ahmad et al. (2011). This part of phytoremediation have not been extensively studied.

\subsection{Phytodesalination}

The plant species which adapted to live in saline environment, a salt-water marsh, locating in seawater, or a salt desert known as halophyte. 24 plant family contain 1100 halophytes which, Amaranthaceous is the biggest family with 353 halophytes (Flowers, 2015a). More than 40 halophyte plant species with high biomass production have been reviewed by Debez et al. (2017). On average more than $90 \%$ of the Na+ in halophytes is in the shoot (Flowers et al., 1977). Halophytes contain succulent leaves and/or steam that contain high content of water per unit area (Flowers, 2015b). So, harvesting of these plant species can permanently decrease salinity of treated soils.

Most recently review on halophytoremediation (Nouri et al., 2017, Nikalje et al., 2019, Cuevas et al., 2019) confirm that targets of halophyte plant species have been concentrated on agricultural issues (desalination) for protecting or improving soil in order to higher production and/or environmental cleaning subjects (heavy metals decontamination). Desalination researches mostly concentrate on A) decrease in soil salinity and sodicity, B) soil quality assessment after desalination with culture of Hordeum vulgare L., and C) halophyte plant capacity for accumulation of salt (Rabhi et al., 2010). Common applications of halophyte plant species are agricultural soil desalination, heavy metal decontamination and desalination (Manousaki and Kalogerakis, 2010), bioenergy production from halophyte biomass by more than 40 species (Debez et al., 2017), and recycling saline wastewater (Panta et al., 2016). Effect of halophyte plant (Echinochloa stagninum) compared with gypsum and ponding method for desalination of soil and livestock fodder carried out in north of Egypt. Results indicate that significant reduction of salinity collected by halophyte plant in compare with gypsum and ponding system.

Identifying dispersive soils and observing their behavior may begin early in the field by manual inspection. The soil type and the extent of soil dispersity are important factors in selecting the appropriate precaution measures. Variation in physical and chemical properties of dispersive soils have been examined by adding different additives such as lime, Zeolite, cement, pozzolan, alum, and lignosulfonate (Savas, 2016, Vakili et al., 2017, Indraratna et al., 2012). The best option must be economically sound too. Notwithstanding a combination of strategies can be simultaneously followed to achieve the most cost effective and viable action plan. Plant application for soil and water decontamination has been recognized as the most cost effective and environmentally sound technique ever (Farraji, 2014; Farraji et al., 2016). Application of halophyte plant species in saline soil (Phytodesalination), in order to improving the geotechnical properties of soil has not been assessed as capable method in dispersive soil improvement. Advantages of phytodesalination for dispersive soil may considered as following tips:

Phytodesalination as a plant-based treatment system is the cost effective treatment method ever for water, air, and soil treatment

- Adaption of this method with the hardest growing condition (high salinity, high temperature and low water availability) and weathers with providing optimum plant growth

- Nature based improvement system for soil (no chemical material addition)

- A sustainable treatment mechanism (permanently decreasing salinity of treated soils)

- Higher guaranteed method by time passing, the more plants growing, and the more desalination.

- Improving the landscaping opportunity in field of dispersive soil

- Presenting the opportunity for plant harvesting (wood and energy source)

- Accordingly, by considering the long and reasonable background for application of halophyte plant species in agricultural land area, phytodesalination may contain reasonable merits for geotechnical soil improvement. Furthermore, phytodesalination may considered as a gap of knowledge for future studies in geotechnical properties of dispersive soils.

\subsection{Phytomicroremediation}

Some parts of phytoremediation may concern to microbial contamination, which is suggested as Phytomicroremediation "Phyto" for the role of plant, "Micro" for microbial pollutants and "Remediation" for the process of decontamination. Treatment of microbial pollutant removal by plant species have not been fully addressed 
yet. Finding capable plant species for specific targets or unsolved and new environmental problems are major parts of phytoremediation, which nowadays recognized as emerging green technology. New Zealand as spectacular ecology have some unique biodiversity, which will prepare suitable explanations for current and future environmental problem pathway, presenting plant species for phytoremediation of microbial pollution (phytomicroremediation). For this side of phytoremediation, the target goal is decontamination of soil from pathogenic microbial contents. Plant species from Myrtaceous (Leptospermum scoparium and Kunzea robusta) have the antiseptic ability for pathogenic microbial community. Tow plant species from Myrtaceae had been used for controlling Escherichia coli and the results of this study, which were carried out in New Zealand, show E-coli concentration decreased significantly (Prosser et al., 2015). Effect of Manuka (Leptospermum scoparium ) in biosolids amended land has been assessed by (Prosser, 2011). This finding illustrates that land application of organic waste, which may introduce microbial pollution for terrestrial media, could be treated by specific types of phytoremediator plant species, which only concentrate on protozoa microbial communities decontamination. Apart from microbial decontamination ability of Kunzea robusta, for $\mathrm{N}_{2} \mathrm{O}$ fluxes from soil was investigated by Franklin (2014). All these researches carried out in New Zealand and more researches in plant ecological origin and other climate zone worldwide needed for improving and categorizing this type of phytoremediation. In terms of aesthetics, these plant species (Figure 4) are attractive for their surrounding areas. Consequently, these plant species not only showed their ability for controlling Escherichia coli in land areas applied for organic waste, but also may contribute to landscape attraction spectacularly in cities area. On the other hand, aerobic sequencing batch reactor (SBR) system normally used for domestic wastewater in cities worldwide, are open area and some parts of microbial communities could be sent to side areas of treatment plants. Microorganism transfer to air mainly occurs during aeration. Air bubbles bursting cause to ejecting a little film of microbial content drop to $15 \mathrm{~cm}$ higher than treatment surface (Warneck, 1999).

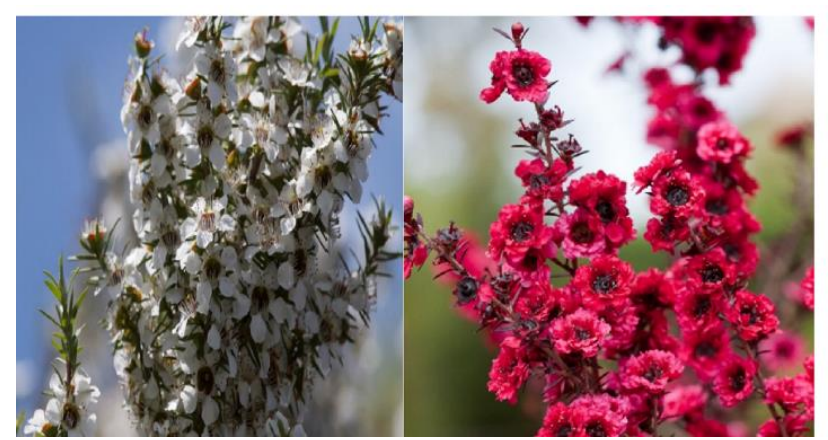

Figure 4. Kunzea robusta (left) and Leptospermum scoparium (right) as capable phyto treatment of microbial pollutants in soil

\subsection{Phytoextraction}

The main specification, which fundamentally forms this technique is pollutants transferring ability of plant species from underground parts to above-ground plant parts and stabilized in plant biomass (Phytostabilization). Based on the report, the woody plants are not capable of transferring track elements to upper parts in semi-arid climate. They studied four plant species and with the exception of Populus alba, other woody plants did not transfer heavy metals to above-ground parts (Domíngue et al., 2008). Based on the report of Robinson et al. (2003, 2019), there are very few commercial phytoextraction operations and these indicate that the efficiency of this method is low. It had been already mentioned by Robinson et al. (1998) that for Zn extraction from mine wastes by Thlapicae rulescens could extract $1 \%$ of total $4 \%$ of the soil $\mathrm{Zn}$ content. Nevertheless, some effective utilizations from phytoextraction have been practically carried out in a natural condition for terrestrial, which polluted by acid mine drainage (Figure 6). It shows that the plant's ability for hyperaccumulation fundamentally depends on characteristic of pollutants, soil content and predicting plant habit, which will be quite hard considering several environmental conditions, climacteric area of phytoextraction project, wide range of amendments, and pollutant specification, especially concentration. Based on the calculation revealed that was carried out by Robinson et al. (2015), for achieving 50\% removal in total metal concentration, there is a requirement for a phytoextraction project with bioaccumulation coefficients of $>10$ within 25 years extraction and consequently, phytoextraction and phytomining are impractical phytotechniques. In other words, they believe that phytomining and phytoextraction are very low-efficiency treatment method even in a very long period of time. Furthermore, those are not only eco-friendly techniques, but also they have several wide ecological footprints. In considering augmentation method for enhancing phytostabilization, such as phytofiltration which can reduce mobility of metals (As) (Bundschuh et al., 2014) and may achieve better cleaning results. 

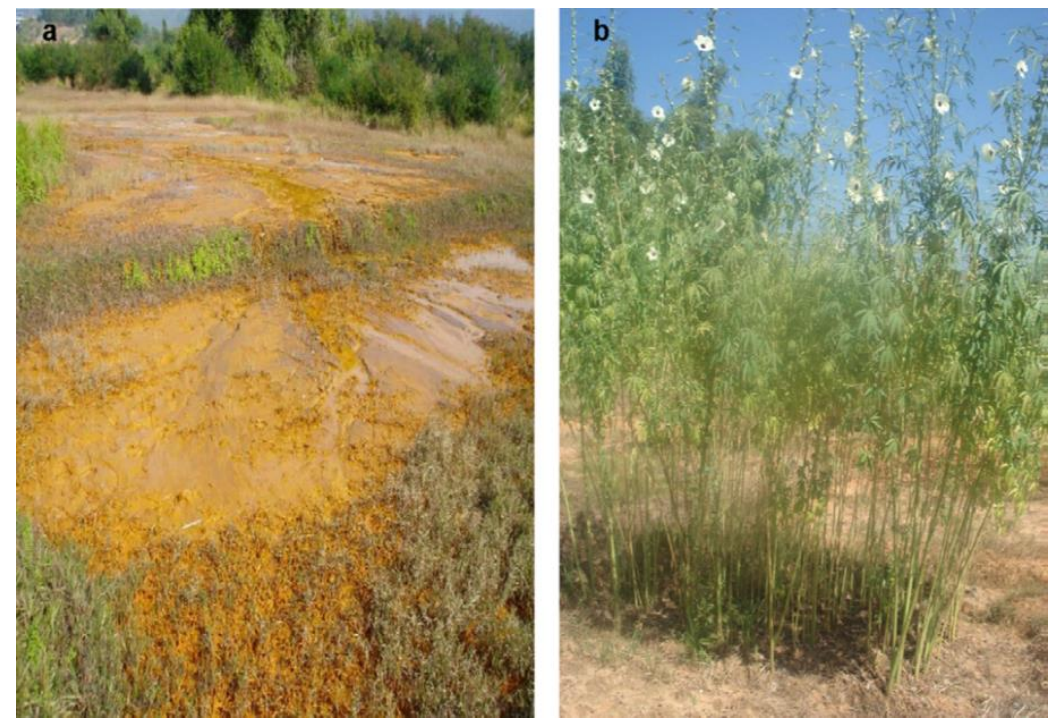

Figure 6. A field trial of polluted soil by acid mine drainage (AMD) in Shangba Village China: a) before b) after kenaf (Hibiscus cannabinus) growing (Xiaoet al., 2008)

\subsubsection{Phytomining}

One of the old applications of phytoremediation(phytoextraction) is phytomining which is known as a promising extraction method for high concentration of pollutants from contaminated areas (Broadhurst et al., 2004). This plant based mining is very simply defined as using plants for precious metal extraction. Gold absorption by plants (Shacklette et al., 1970), gold in plants (Girling and Peterson, 1980) gold harvest by plant (Anderson et al., 1998) and gold uptake by plants (Anderson et al., 1999) are numbers of preliminary investigation on phytomining. Hyperaccumulator plant species are the phytoremediation macrophyte which used in phytomining process (Chaney et al., 2007; Chaney et al., 2005; Raskin et al., 1997). Phytoremediation contains some disadvantages, such as timeconsuming process, limited bioaccumulation capacity, highly depended to plant growth and tolerant to metallic elements, available surface area and root depth (Farraji et al., 2016). Based on the report by Witters et al. (2012), $\mathrm{CO} 2$ abatement through the phytoremediation process in polluted area should be considered as new attractive aspect of phytoremediation vs disadvantages of this green technology. By considering more than 400 hyperaccumulator plant spices for $\mathrm{Ni}$, phytomining of this valued metal is concerning of many researches (Zhang et al., 2016). Thus, economic value of the extracted metal is the first motive of the recovering process (Chaney, 1983). Furthermore, plant biomass and availability of decontaminated soil for normal application are other economic feasibilities of phytomining (Brooks et al., 1998). The native plants application for phytomining in aspects of practical reasons and assistant the maintenance of serpentine biodiversity successfully implemented in Albania Alyssum murale (Bani et al., 2015; Bani et al., 2007). Hyperaccumulator plant species can directly be used in contaminated terrestrial area (Harris et al., 2009) or in contaminated solution (aquatic media) for directly extraction precious metallic elements (Anderson et al., 1998). This technique contains two precious opportunities, namely decontamination of polluted soil and extracting expensive metallic elements. The other unique specification of phytomining is recouping possibility for phytoremediation process by the earning money from extracted metals (LaCoste et al., 2001). In the phytoextraction process, the main goal is remediation, degraded of pollutants or accumulate of metallic elements in harvestable parts of high tolerant plant species. Nevertheless, phytomining looks to recover metals from the harvestable parts of hyperaccumulator plant species (Chaney et al., 2007; Ye-Tao et al., 2012). Based on the literatures, the plant species which are selected for phytomining should have following characteristics (Brooks et al., 1998; Li et al., 2003a; Vangronsveld et al., 2009).

- Capable for producing high volume of biomass

- High tolerance to metallic elements

- Ability to growing in highly contaminated media

- High capacity to accumulation of target elements in plant parts

- They should be either natural hyperaccumulator or induced by artificial methods

The plants with aforementioned specification would be applied in mineralized soil or low-grade ore and after harvesting, biomass should be incinerated in order to bio-ore production. Meanwhile, low biomass production of most Ni hyperaccumulator plant species (Alyssum serpyllifolium ssp. lustanicum, Noccaea goesingense, Alyssum bertolonii and A. serpyllifolium ssp. malacitanum ) reported by (Álvarezet al., 2016). Figure 5 shows schematic process of phytomining and Table 3 presents numbers of phytomining researches. 


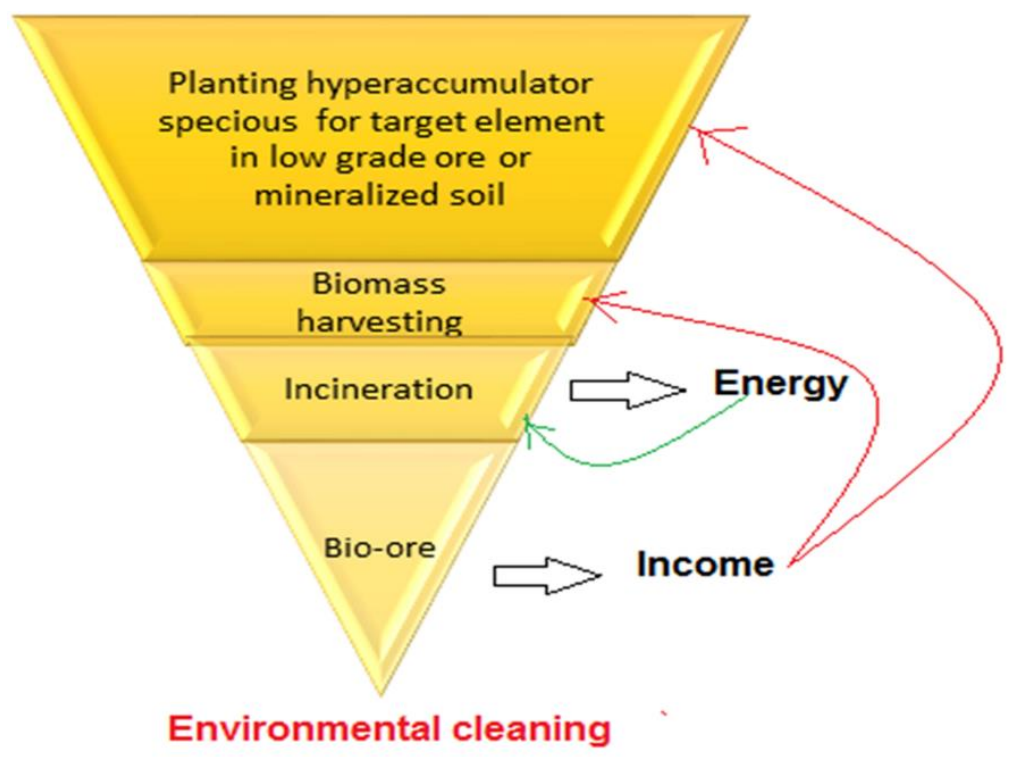

Figure 7. Schematic process of phytomining based on the (Brooks et al., 1998)

Table 3. Numbers of phytomining studies

\begin{tabular}{|c|c|c|c|c|}
\hline Plant species /common name & 冚 & Production & Results & Reference \\
\hline $\begin{array}{l}\text { Biscutella laevigata } \\
\text { Iberisin termedia }\end{array}$ & $\mathrm{Tl}$ & $\begin{array}{l}\text { Thallium bio-ore } \\
\text { Energy }\end{array}$ & $\begin{array}{l}\text { Acceptable concentration of } \\
\text { Th in soil }\end{array}$ & $\begin{array}{l}\text { (LaCoste et } \\
\text { al., 1999) }\end{array}$ \\
\hline $\begin{array}{l}\text { Iberisin termedia } \\
11 \text { common vegetables }\end{array}$ & $\mathrm{Tl}$ & $\begin{array}{l}\text { Thallium bio-ore } \\
\text { Energy }\end{array}$ & $\begin{array}{l}\text { Common vegetables are not } \\
\text { suitable } \\
\text { Iberisin termedia in } 5 \\
\text { sequential }\end{array}$ & $\begin{array}{l}\text { (LaCoste et } \\
\text { al., 2001) }\end{array}$ \\
\hline $\begin{array}{l}\text { Green cabbage }>\text { carrot }>\text { chili }> \\
\text { Chinese cabbage }>\text { rice }>\text { corn } \\
\text { Respectively Tl concentration }\end{array}$ & $\mathrm{Tl}$ & $\begin{array}{l}\text { Soil cleaning }+ \\
\text { health care and } \mathrm{Tl} \\
\text { mining }\end{array}$ & $\begin{array}{l}\text { Green cabbage concentrate } \\
500 \mathrm{mg} / \mathrm{kg} \text { dry wt Thallium }\end{array}$ & $\begin{array}{l}\text { (Xiao et al., } \\
2004)\end{array}$ \\
\hline Alyssum murale & $\mathrm{Ni}$ & $\begin{array}{l}6.3 \mathrm{t} \mathrm{ha}^{-1} \text { biomass }+ \\
9129 \mathrm{mgkg}^{-1} \\
\text { Ni in shoots }\end{array}$ & $\begin{array}{l}\text { Extensive phytomining } \\
\text { augmented by fertilization }\end{array}$ & $\begin{array}{l}\text { (Bani et al., } \\
2007 \text { ) }\end{array}$ \\
\hline $\begin{array}{l}\text { Cicer arietinum } \\
\text { Piptatherum milliaceum } \\
\text { Lygeum spartum }\end{array}$ & $\begin{array}{l}\mathrm{Pb} \\
\mathrm{Cd} \\
\mathrm{Cu} \\
\mathrm{Zn}\end{array}$ & $\begin{array}{l}\text { Saving agricultural } \\
\text { areas }\end{array}$ & $\begin{array}{l}\text { Highest concentration in the } \\
\text { roots of } P \text {. milliaceum }\end{array}$ & $\begin{array}{l}\text { (Conesa et } \\
\text { al., 2009) }\end{array}$ \\
\hline $\begin{array}{l}\text { Berkheya coddii } \\
\text { Bressica juncea }\end{array}$ & $\mathrm{Ni}$ & $\begin{array}{l}\text { Economic } \\
\text { feasibility by } \\
\text { phytomining }\end{array}$ & $\begin{array}{l}\text { Profitability is very sensitive } \\
\text { to the price of metal and the } \\
\text { extraction of target metal }\end{array}$ & $\begin{array}{l}\text { (Harris et al., } \\
\text { 2009) }\end{array}$ \\
\hline $\begin{array}{l}\text { Alyssum corsicum } \\
\text { Alyssum malacitanum } \\
\text { Alyssum murale } \\
\text { Noccaea goesingense }\end{array}$ & $\mathrm{Ni}$ & $\begin{array}{l}\text { Auxin have } \\
\text { positive effect on } \\
\text { Ni accumulation }\end{array}$ & $\begin{array}{l}\text { Biomass increasing by } \\
\text { hormone augmentation have } \\
\text { no linear correlation with } \\
\text { accumulated } \mathrm{Ni}\end{array}$ & $\begin{array}{l}\text { (Cabello et } \\
\text { al., 2014b) }\end{array}$ \\
\hline Alyssum murale & $\mathrm{Ni}$ & $\begin{array}{l}30 \text { times biomass } \\
\text { production and } 100 \\
\text { times } \mathrm{Ni} \\
\text { accumulation }\end{array}$ & $\begin{array}{l}\text { Positive effect of Weed } \\
\text { control } \\
\text { Time optimized cropping } \\
\text { Fertilizing on biomass } \\
\text { production }\end{array}$ & $\begin{array}{l}\text { (Bani et al., } \\
2015 \text { ) }\end{array}$ \\
\hline $\begin{array}{l}\text { Bornmuellera tymphaea } \\
\text { and } \\
\text { Noccaea tymphaea }\end{array}$ & $\mathrm{Ni}$ & \begin{tabular}{lr}
\multicolumn{2}{l}{ Type of planting } \\
Mixed & planting \\
positive & effect \\
illustrated & \\
\end{tabular} & $\begin{array}{llr}\begin{array}{l}\text { Combination of } \\
\text { hyperaccumulator } \\
\text { positive effect on } \\
\text { hyperaccumulation }\end{array} & & \\
\end{array}$ & $\begin{array}{l}\text { (Rue et al., } \\
2015)\end{array}$ \\
\hline $\begin{array}{l}\text { Bornmuellera typhaea }- \text { Noccaea } \\
\text { tymphaea }\end{array}$ & $\mathrm{Ni}$ & $\begin{array}{l}\text { Amount } \quad \text { of } \\
\text { extracted Ni, } 66.4 \%\end{array}$ & $\begin{array}{l}\text { PGPR have positive effect on } \\
\mathrm{Ni} \text { accumulation }\end{array}$ & $\begin{array}{l}\text { (Durand et } \\
\text { al., 2015) }\end{array}$ \\
\hline
\end{tabular}


Farraji et al.

Phytoremediation: green technology for improving aquatic and terrestrial environments

\begin{tabular}{|c|c|c|c|c|}
\hline $\begin{array}{l}\text { Bornmuellera typhaea-alyssum } \\
\text { murale }\end{array}$ & & $\begin{array}{l}\text { in root and } 79.6 \% \\
\text { in shoots }\end{array}$ & & \\
\hline $\begin{array}{l}\text { Alyssum serpyllifolium ssp. } \\
\text { lustanicum } \\
\text { A. serpyllifolium } \text { ssp. malacitanum } \\
\text { Noccaea goesingense } \\
\text { Alyssum bertolonii }\end{array}$ & $\mathrm{Ni}$ & $\begin{array}{l}\text { Application of the } \\
\text { organic wastes as } \\
\text { amendment }\end{array}$ & $\begin{array}{l}\text { Compost as organic } \\
\text { amendment could be } \\
\text { considered as incorporated } \\
\text { into phytomining }\end{array}$ & $\begin{array}{l}\text { (Álvarez et } \\
\text { al., 2016) }\end{array}$ \\
\hline $\begin{array}{l}\text { Odontarrhena bracteata, } \\
\text { O. inflata, } \\
\text { O. serpyllifolia }\end{array}$ & $\mathrm{Ni}$ & $\begin{array}{l}\text { Significant effect of } \\
\text { plant } \quad \text { species } \\
\text { proved }\end{array}$ & $\begin{array}{lr}\text { Manure } & \text { amendment and } \\
\text { Bacterial } & \text { inoculation } \\
\text { enhanced extracted } \mathrm{Ni}\end{array}$ & $\begin{array}{l}\text { (Ghasemi et } \\
\text { al., 2018) }\end{array}$ \\
\hline $\begin{array}{lr}\text { Bornmuellera } & \text { emarginata } \\
\text { Noccaea } & \text { caerulescens } \\
\text { Odontarrhena } & \text { muralis } \\
\text { Odontarrhena serpyllifolia. }\end{array}$ & $\mathrm{Ni}$ & $\begin{array}{l}2.9 \mathrm{~kg} / \mathrm{ha} \\
1.9 \mathrm{~kg} / \mathrm{ha} \\
2.3 \mathrm{~kg} / \mathrm{ha} \\
-\end{array}$ & $\begin{array}{l}\text { Compost amended plots } \\
\text { produced higher biomass }\end{array}$ & $\begin{array}{l}\text { (Cerdeira- } \\
\text { Pérez et al., } \\
2019)\end{array}$ \\
\hline $\begin{array}{ll}\text { Odontarrhena } & \text { chalcidica } \\
\text { Noccaea goesingensis } & \\
\end{array}$ & $\mathrm{Ni}$ & $\begin{array}{l}55 \mathrm{~kg} / \mathrm{ha} \\
36 \mathrm{~kg} / \mathrm{ha}\end{array}$ & $\begin{array}{l}\text { Sulphur implementation } \\
\text { High density planting }\end{array}$ & $\begin{array}{l}\text { (Rosenkranz } \\
\text { et al., 2019) }\end{array}$ \\
\hline Odontarrhena chalcidica & $\mathrm{Ni}$ & $\begin{array}{l}\text { Max } \quad \text { uptake } \\
26.8 \mathrm{~g} \mathrm{~kg}^{-1} \mathrm{Ni}\end{array}$ & $\begin{array}{l}\text { Positive effect of fertilizing } \\
\text { for higher Ni uptake }\end{array}$ & $\begin{array}{l}\text { (Tognacchin } \\
\text { i et al., 2020) }\end{array}$ \\
\hline
\end{tabular}

Based on the report of Australian researchers (Harris et al., 2009), in the future phytomining appears to be the most viable technique, where there are comparatively extremely high metallic elements concentration especially around the abandoned mines and plants, which process metals. In Portugal, researches of Alves et al. (2019) indicated additional income source for local farmers in $\mathrm{Ni}$ agromining by Alyssum serpyllifolium subsp. Lusitanicum. Nevertheless, New Zealand scientists, Robinson et al. (2015) illustrate that: this phytotechnology suffers from low efficiency of precious metals extraction rates. Meanwhile, Álvarez et al. (2016) indicate that organic wastes amendment causes the recycling of these residues through the phytomining as enhancing advantages of this cleaning method. Positive effect of cropping, fertilization, and weed control through the Ni phytomining has increased biomass production to 30 times and 100 times of phytoextracted $\mathrm{Ni}$ in comparison with normal growing (Bani et al., 2015). Arthrobacter nicotinovorans SA40 was reported as rhizobacteria for augmenting Ni uptake and accumulation (Cabello et al., 2014a). Application of plant hormones such as Gibberellins and Cytokinins reduces metal accumulation (Cabello et al., 2014b). Finally, "Agromining" concept are presented by Van Der Ent et al. (2015), a team of expert scientists from Australia, Canada, China, France, New Caledonia, New Zealand and United States, as future policy for decontamination method by agro-plant application against "phytomining ". In this method, all process of planting, fertilizing, weed control, cropping and final harvesting will be planned as an agricultural farming process. Thus, future technical improvement and scientific research, such as enhancing metal yield amendment techniques (Álvarez et al., 2016), productivity by co-cropping of legume (Jiang et al., 2015) or increasing purity of final production (Zhang et al., 2016) as well as the economic value of metallic elements and human requirement will assume the role of agromining as improved and advanced phytomining.

\section{FUDAMENTAL OD PHYTOREMEDIATION}

\subsection{Phytoaccumulation}

Phytoaccumulation defined as accumulation of trace elements in phytoremediator plant species. Hazardous metallic element accumulation from aquatic media with Lemna minor L. (Zayed et al., 1998), Eichhornia crassipes (Zhu et al., 1999), Myriophyllum aquaticum, Mentha aquatic and Ludwigina palustris (Kamal et al., 2004) and terrestrial plant species such as Helianthus annuus, Nicotiana tabacum and Vetiveria zizanioides (Boonyapookana et al., 2005), Solanum tuberosum L. (Baghour et al., 2001) and Brassica juncea (Shahandeh and Hossner, 2000). These researchers finally report the selectivity or ordering of trace elements by plant species such as $\mathrm{Hg}>\mathrm{Fe}>\mathrm{Cu}>\mathrm{Zn}$ (Kamal et al., 2004) or $\mathrm{Cu}>\mathrm{Se}>\mathrm{Pb}>\mathrm{Cd}>\mathrm{Ni}>\mathrm{Cr}$ (Zayed et al., 1998) in presenting eligible plant species for specific pollutant removal. By considering accumulated metallic elements in root, shoots, and leaves as under grand and upper grand parts of the plant, phytoaccumulation studies may present new hyperaccumulators for future application. This section of phytoremediation has been fully addressed in literatures both aquatic and terrestrial media and the collected information by phytoaccumulation is used as input data for several other scientific lab scales, field or full-scale studies. Phytoaccumulation categorized as phytoextraction by (Reichenauer and Germida, 2008). 


\subsection{Hyperaccumulation}

Contaminated soils are the major source of heavy metals uptaking by plants. Toxic effects of heavy metals cause several serious physiological and structural damages for plants. Tolerance to low or high concentration of heavy metals depends on plant physiology and genetics. Finding naturally grown species in highly polluted soils could be considered as the usual method for distinguishing and collecting hyperaccumulator plants. In the accumulation of metallic elements, the characteristics of a hyperaccumulator species are at least 100 times more than nonhyperaccumulator species (Brooks and Farago, 1994). Meanwhile, an unusual hyperaccumulator with more than 500 $\mu \mathrm{g} / \mathrm{g}$ dry mass (Iberis intermedia) was found in France (Leblanc et al., 1999). Numbers of hyperaccumulator plant species increased from 400 species (Baker et al., 2000) to 500 species by Ma et al. (2001). This emerging issue is continued in finding specific hyperaccumulator for single heavy metal. Nowadays, 450 Ni hyperaccumulators (Van der Ent et al., 2013a) and the vast majority of these plant species which are known as natural hyperaccumulators of $\mathrm{Ni}$, are endemic to soil developed over rocks that named "ultramafic rocks" with high concentration of metallic elements such as $\mathrm{Co}, \mathrm{Cr}$ and $\mathrm{Ni}$ (Reeves, 2006). In another case, $400 \mathrm{Cd}$ hyperaccumulator plant species reported by (Hakeem et al., 2014).

The process of phytoextraction and phytomining by natural hyperaccumulator plant species can effectively cause decontamination of polluted soils (Raskin et al., 1997). Lake of scientific knowledge about basic plant species process is the main limitation of this high potential of natural hyperaccumulator for decontamination of polluted media (PilonSmits, 2005). Genetic modification as basement of hyperaccumulation process and traditional breeding systems as improving the specification method, are two main aspects of a clear picture, which will give for mechanism of metals the entrance to plant roots and the process, which finally cause the translocation of metallic elements to upper parts of hyperaccumulator plants (McGrath and Zhao, 2003).

There are new types of hyperaccumulation system, which are a non-hyperaccumulator species and industrial crop production species with hyperaccumulator behavior. This type of plants naturally could not be considered as hyperaccumulator. Nevertheless, with augmentation of nutrients through the growing, addition of specific adsorbent such as biochar, these augmentations could be applicable in preparing better circumstances for higher biomass production by natural hyperaccumulator or decreasing toxicity of heavy metals for normal, moderate or crop species to present hyperaccumulation behaviors. Biochar application as a simple soil augmentation could decrease available heavy metals for non-hyperaccumulator plant species, such as Zea mays while Lolium perenme and increase root specific surface in order to root proliferation (Rees et al., 2016). Therefore, it can be a suitable application of crop plants as high uptaking species with extremely high biomass production, which finally cause to higher and efficiency of heavy metal extraction in shorter time.

\subsection{Mechanisms of metals accumulation}

The major mechanisms involving hyperaccumulation of metallic element are:

- $\quad$ Roots and microbes interaction cause to bioactivation of metallic elements in rhizosphere

- Metal sequestration by tonoplast transporters in the vacuole

- In the plasma membranes of hyperaccumulator species, there are transporter organism which enhance heavy metals uptaking

- $\quad$ Ligands such as protein with metal binding, phytochelatins, and metallothioneins in the cell walls of the cytoplasm make a chelation in order to metal detoxification (Yang et al., 2005)

- The metallothionein mechanism could be considered as a suitable stress response in the context of metallic elements (Janssens et al., 2009)

Cadmium and lead as high toxic heavy metals, which have a harmful effect on plants and animals even in low concentration, will be assessed here as metallic elements. A concentration of $100 \mathrm{mg} / \mathrm{kg} \mathrm{d.wt}(0.01 \%)$ is a base volume of Cd for a hyperaccumulator plant species (Baker et al., 2000). Only Sedum alfredii (Sun et al., 2007) and Thlaspicae rulescens (Basic et al., 2006) are plant species, which are reported as Cd hyperaccumulator. Thlaspicae rulescens, which are grown in metal polluted soil, had a high root to shoot ratio and higher biomass production in comparison with same species that were growing in non-polluted soils (Dechamps et al., 2005). Cadmium accumulation could be seen as polymorphism characteristics in Thlaspicae rulescens which is a suitable case for increasing knowledge of hyperaccumulation mechanism and based on the report of Basic et al. (2006), molecular data could be used for distinguishing these types of hyperaccumulator plants. Translocation of cadmium from root to shoot usually carried out by the xylem and this process driven by leaf transpiration (Ueno et al., 2008; Uraguchi et al., 2009). Furthermore, positive effect of transpiration on $\mathrm{Cd}$ translocation as a clear relationship between two physiological activities of the plant is reported for Phytolacca Americana by (Xiaoqing et al., 2010). Process of root 
uptaking of $\mathrm{Cd}$ and loading in xylem and finally translocation to above ground (shoots), symplastic pathway are more contributed than apoplastic bypass. It suggested by Qin et al. (2013) that high mobility for Cd in both the phloem, xylem and stems have a major role in transferring through these pathways. Concentration of Cd in plant parts is by order of shoots > roots > leaves (Kirkham, 2006; Sun et al., 2007). In a recently mechanism study of hyperaccumulation process, Liu et al. (2016) presented an active-passive pathway for Cd uptaking in tobacco. Figure 7 illustrates two-step mechanism for cadmium translocation in Nicotiana tabacum L. As it can be seen in translocation of $\mathrm{Cd}$ from roots to stem, the main role belongs to leaves transpiration.

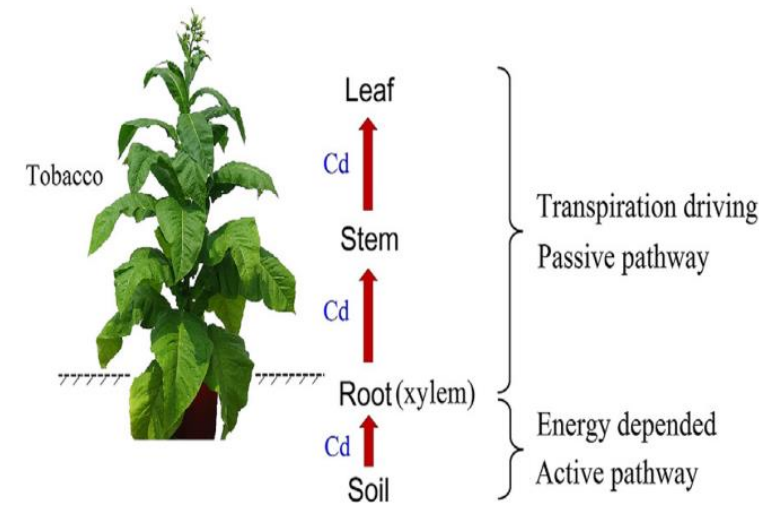

Figure 8. Two-step translocation mechanism for Cd in tobacco plants (Liu et al., 2016)

There is no biological function for lead $(\mathrm{Pb})$ in plant, however, this non-biodegradable high toxic metallic element accumulated by plant in high concentration volume in shoots > roots (Farraji et al., 2014). Furthermore, there is a significant correlation between $\mathrm{Pb}$ concentration in plants tissues and lead concentration in soil (Kabata-Pendias, 2010). Only the plant species with more than $1 \%$ lead in their upper part could be considered as qualified high biomass plant species, such as Sesbania drummondii for Pb extraction as hyperaccumulator (Sahi et al., 2002). Lead is the most immobile heavy metal compare to $\mathrm{Cd}, \mathrm{Cu}, \mathrm{Zn}, \mathrm{Ni}$ and $\mathrm{Cr}$ (Kumar et al., 1995). On the other hand, attendance of organic matters decrease the risk of contamination transport to the groundwater (Mohajeri et al., 2018) so, for enhancing translocation of lead in soil media and plant tissues, some amendments such as chelators beside acidifier could be a suitable method (Salt et al., 1995). In a research on Salvinia minima as hyperaccumulator of $\mathrm{Pb}$ and Cd (Sánchez-Galván et al., 2008), intracellular accumulation and bioadsorption are mentioned as contribute mechanisms for hyperaccumulation process. It is necessary to shade more light on the uptake mechanism by genome studies (Janssens et al., 2009).

\section{CONCLUSION}

Phytoremediation as an emerging technology in environmental cleaning is going to be considered as one of major treatment or post treatment methods for improving soil and water quality (Farraji et al., 2020). Phytoremediation as a technique follows a naturalistic style of adaptation with pollutants. Atmospheric, terrestrial and aquatic media could be the targets of decontamination for this technique. Wide range of contaminants contains degradable and/or nondegradable, organic and/or inorganic could be treated by this technique. Furthermore, the concentration of pollutants in this green treatment system is extremely wide. In other words, for numerous type and/or concentration of pollutants, phytoremediation as treatment methods, has the uniqueness of characteristics, such as sustainable and cost effective. Phytoremediation is highly adaptive as co-treatment (Jesus et al., 2015), electro-treatment (Cameselle \& Gouveia, (2019), and post treatment (Schwantes et al., 2019). The most important factor in the application of this eco-friendly technology is the proper selection of suitable phytoremediators and preparing promotional augmentation for enhancing the efficiency in comfortable circumstances. As a matter of fact, even after two decades of utilization from phytoremediation for environmental cleaning, there is no union system of standard terms and application method, plant density and even definition of applied words, which causes facing on enormous non-comparative researches on phytoremediation. When Salt et al. (1995) define three subsets (1) phytoextraction, (2) Rhizofiltration and (3) phytostabilization for phytoremediation, it was unthinkable to them that in approximately two decades subsets will rapidly increase. Strict requirement seems to be needed for standardization and classification for all types and process of these treatment methods in order to put it in a framework of a global recognized organization. There are many black and white observation about this technique, while the attraction of unknown specification and novel abilities of this "phyto" base treatment converted it into one of the most highly cited issues in researches. This treatment system is widely applied in some commercial cases such as landfill covering and is going to be major 
treatment method for municipal wastewater in few future. On the other hand, this technique suffers from long time requirement and high sensitivity to the concentration of pollutants, especially complex metallic elements and suspended solids. Furthermore, utilization of this technique as economically feasible treating technique in terrestrial phytoextraction is faced with fundamental arguments. Nowadays, many new aspects of the knowledge, such as augmentation (microorganisms) and amendment techniques (nutrients and organic matters ) for promoting uptake efficiency, are going to be a constant part of phytoremediation as well as planting, harvesting, weed control, and multicultural utilization of phytoremediator plant species, which are often considered in phytoremediation plans. There are several unknown and mysteries sides about this technique which future studies will need to be concerned about to give a clear picture on phytoremediation.

1. The following tips may be considered as future research area:

2. Finding specific phytoremediation technique for high suspended solid wastewater

3. Finding natural multi metallic element hyperaccumulator plant species

4. Optimization of nutrients, mycorrhiza and promoter augmentation

5. Enhancing the efficiency of multipollutant removal in natural condition

6. Specifying fast and high performance phytoremediation techniques

7. Agricultural application of contaminated areas

8. Biomass management for sustainable phytoremediation process

9. Air / noise pollution control in industrial and municipal regions by phytoremediation

Acknowledgements: We thank Institute of Scientific Researches Amin Azma for their support during this study. Authors declare that there is no conflict of interest.

Conflict of Interest: Authors declare that there is no conflict of interest.

\section{REFERENCES}

Abhilash, P., Pandey, V.C., Srivastava, P., Rakesh, P., Chandran, S., Singh, N., Thomas, A. (2009). Phytofiltration of cadmium from water by Limnocharis flava (L.) Buchenau grown in free-floating culture system. Journal of Hazardous Materials, 170(2), 791-797. https://doi.org/10.1016/j.jhazmat.2009.05.035

Abu-Erreish, G., Whitehead, E., Olson, O. (1968). Evolution of volatile selenium from soils. Soil Science, 106(6), 415-420.

Adler, P.R., Arora, R., El Ghaouth, A., Glenn, D.M., Solar, J.M. (1994). Bioremediation of phenolic compounds from water with plant root surface peroxidases. Journal of Environmental quality, 23(5), 1113-1117. https://doi.org/10.2134/jeq1994.00472425002300050038x

Agostini, E., Talano, M.A., González, P.S., Oller, A.L.W., Medina, M.I. (2013). Application of hairy roots for phytoremediation: what makes them an interesting tool for this purpose? Applied Microbiology and Biotechnology, 97(3), 1017-1030. https://doi.org/10.1007/s00253-012-4658-z

Ahmad, A., Ghufran, R., Zularisam, A. (2011). Phytosequestration of metals in selected plants growing on a contaminated Okhla industrial areas, Okhla, New Delhi, India. Water, Air, \& Soil Pollution, 217(1-4), 255266. https://doi.org/10.1007/s11270-010-0584-9

Ahmaruzzaman, M. (2011). Industrial wastes as low-cost potential adsorbents for the treatment of wastewater laden with heavy metals. Advances in Colloid and Interface Science, 166(1), 36-59. https://doi.org/10.1016/j.cis.2011.04.005

Akhundova, E., Atakishiyeva, Y. (2015). Interaction Between Plants and Biosurfactant Producing Microorganisms in Petroleum Contaminated Absheron Soils. Phytoremediation for Green Energy (pp. 115-122): Springer. https://doi.org/10.1007/978-94-007-7887-0 7

Albert, Q., Baraud, F., Leleyter, L., Lemoine, M., Heutte, N., Rioult, J.P., Garon, D. (2019). Use of soil fungi in the biosorption of three trace metals $(\mathrm{Cd}, \mathrm{Cu}, \mathrm{Pb})$ : promising candidates for treatment technology?. Environmental Technology, 1-12. https://doi.org/10.1080/09593330.2019.1602170

Alderete, L., Ibáñez, S., Agostini, E., Medina, M. (2012). Phytoremediation of phenol at pilot scale by tobacco hairy roots. International Journal of Environmental Sciences, 3(1), 398-407. https://doi.org/10.6088/ijes.2012030131038

Alderete, L.G.S., Talano, M.A., Ibáñez, S.G., Purro, S., Agostini, E., Milrad, S.R., Medina, M.I. (2009). Establishment of transgenic tobacco hairy roots expressing basic peroxidases and its application for phenol removal. Journal of Biotechnology, 139(4), 273-279. https://doi.org/10.1016/j.jbiotec.2008.11.008 
Alkorta, I., Garbisu, C. (2001). Phytoremediation of organic contaminants in soils. Bioresource Technology, 79(3), 273-276. https://doi.org/10.1016/S0960-8524(01)00016-5

Álvarez-López, V., Prieto-Fernández, Á., Cabello-Conejo, M., \& Kidd, P. (2016). Organic amendments for improving biomass production and metal yield of Ni-hyperaccumulating plants. Science of the Total Environment, 548, 370-379. https://doi.org/10.1016/j.scitotenv.2015.12.147

Alves, A.R., Silva, E.F., Novo, L.A. (2019). Morais Ultramafic Complex: A Survey towards Nickel Phytomining. Resources, 8(3), 144. https://doi.org/10.3390/resources8030144

Anderson, C.W., Brooks, R.R., Stewart, R.B., Simcock, R. (1998). Harvesting a crop of gold in plants. Nature, 395(6702), 553-554. https://doi.org/10.1038/26875

Anderson, C.W., Brooks, R.R., Stewart, R.B., Simcock, R. (1999). Gold uptake by plants. Gold Bulletin, 32(2), 4852. https://doi.org/10.1007/BF03214790

Arshad, M., Saleem, M., Hussain, S. (2007). Perspectives of bacterial ACC deaminase in phytoremediation. TRENDS in Biotechnology, 25(8), 356-362. https://doi.org/10.1016/j.tibtech.2007.05.005

Awa, S.H., Hadibarata, T. (2020). Removal of Heavy Metals in Contaminated Soil by Phytoremediation Mechanism: a Review. Water, Air, \& Soil Pollution, 231(2), 47. https://doi.org/10.1007/s11270-020-4426-0

Baghour, M., Moreno, D., Hernandez, J., Castilla, N., Romero, L. (2001). Influence of root temperature on phytoaccumulation of $\mathrm{As}, \mathrm{Ag}, \mathrm{Cr}$, and $\mathrm{Sb}$ in potato plants (Solanum tuberosum L. var. Spunta). Journal of Environmental Science and Health, Part A, 36(7), 1389-1401. https://doi.org/10.1081/ESE-10010886

Baker, A.J., McGrath, S., Reeves, R.D., Smith, J., Terry, N., Bañuelos, G. (2000). A review of the ecology and physiology of a biological resource for phytoremediation of metal polluted soils. Phytoremediation of contaminated soil and water (Eds: Terry N, Banuelos G and Vangronsveld J). CRC Press, Boca Raton, Florida, USA, 85-107.

Bani, A., Echevarria, G., Sulçe, S., Morel, J.L. (2015). Improving the agronomy of Alyssum murale for extensive phytomining: a five-year field study. International Journal of Phytoremediation, 17(2), 117-127. https://doi.org/10.1080/15226514.2013.862204

Bani, A., Echevarria, G., Sulçe, S., Morel, J.L., Mullai, A. (2007). In-situ phytoextraction of Ni by a native population of Alyssum murale on an ultramafic site (Albania). Plant and soil, 293(1-2), 79-89. https://doi.org/10.1007/s11104-007-9245-1

Basic, N., Salamin, N., Keller, C., Galland, N., Besnard, G. (2006). Cadmium hyperaccumulation and genetic differentiation of Thlaspi caerulescens populations. Biochemical Systematics and Ecology, 34(9), 667-677. https://doi.org/10.1016/j.bse.2006.04.001

Baudoin, E., Benizri, E., Guckert, A. (2003). Impact of artificial root exudates on the bacterial community structure in bulk soil and maize rhizosphere. Soil Biology and Biochemistry, 35(9), 1183-1192. https://doi.org/10.1016/S0038-0717(03)00179-2

Bisht, S., Pandey, P., Kaur, G., Aggarwal, H., Sood, A., Sharma, S., Bisht, N. (2014). Utilization of endophytic strain Bacillus sp. SBER3 for biodegradation of polyaromatic hydrocarbons (PAH) in soil model system. European Journal of Soil Biology, 60, 67-76. https://doi.org/10.1016/j.ejsobi.2013.10.009

Bora, M.S., Sarma, K. P. (2020). Phytoremediation of Heavy Metals/Metalloids by Native Herbaceous Macrophytes of Wetlands: Current Research and Perspectives. In Emerging Issues in the Water Environment during Anthropocene (pp. 261-284). Springer, Singapore. https://doi.org/10.1007/978-981-32-9771-5_14

Boonyapookana, B., PreedaJugsujinda, A. (2005). Phytoaccumulation of lead by sunflower (Helianthus annuus), tobacco (Nicotiana tabacum), and vetiver (Vetiveria zizanioides). Journal of Environmental Science and Health, 40(1), 117-137. https://doi.org/10.1081/ESE-200033621

Broadhurst, C.L., Chaney, R.L., Angle, J.S., Maugel, T.K., Erbe, E.F., Murphy, C.A. (2004). Simultaneous hyperaccumulation of nickel, manganese, and calcium in Alyssum leaf trichomes. Environmental Science \& Technology, 38(21), 5797-5802.

Brooks, R.R., Chambers, M.F., Nicks, L.J., Robinson, B.H. (1998). Phytomining. Trends in plant science, 3(9), 359362. https://doi.org/10.1016/S1360-1385(98)01283-7

Brooks, R.R., Farago, M. (1994). Plants that hyperaccumulate heavy metals. Plants and the chemical elements. Biochemistry, uptake, tolerance and toxicity, 88-105.

Bundschuh, J., Holländer, H.M., Ma, L.Q. (2014). In-situ Remediation of Arsenic-contaminated Sites: CRC Press.

Cabello-Conejo, M., Becerra-Castro, C., Prieto-Fernández, A., Monterroso, C., Saavedra-Ferro, A., Mench, M., Kidd, P. (2014a). Rhizobacterial inoculants can improve nickel phytoextraction by the hyperaccumulator Alyssum pintodasilvae. Plant and soil, 379(1-2), 35-50. https://doi.org/10.1007/s11104-014-2043-7 
Cabello-Conejo, M., Prieto-Fernández, Á., Kidd, P. (2014b). Exogenous treatments with phytohormones can improve growth and nickel yield of hyperaccumulating plants. Science of the total environment, 494, 1-8. https://doi.org/10.1016/j.scitotenv.2014.06.102

Cameselle, C., Gouveia, S. (2019). Phytoremediation of mixed contaminated soil enhanced with electric current. Journal of Hazardous materials, 361, 95-102. https://doi.org/10.1016/j.jhazmat.2018.08.062

Cang, L., Wang, Q. Y., Zhou, D. M., Xu, H. (2011). Effects of electrokinetic-assisted phytoremediation of a multiplemetal contaminated soil on soil metal bioavailability and uptake by Indian mustard. Separation and purification technology, 79(2), 246-253. https://doi.org/10.1016/j.seppur.2011.02.016

Cao, X., Ma, L.Q., Tu, C. (2004). Antioxidative responses to arsenic in the arsenic-hyperaccumulator Chinese brake $\begin{array}{lllll}\text { fern (Pteris vittata } & \text { L.). Environmental Pollution, 128(3), 325. }\end{array}$ https://doi.org/10.1016/j.envpol.2003.09.018

Cerdeira-Pérez, A., Monterroso, C., Rodríguez-Garrido, B., Machinet, G., Echevarria, G., Prieto-Fernández, Cerdeira-Pérez, A., Monterroso, C., Rodríguez-Garrido, B., Machinet, G., Echevarria, G., Prieto-Fernández, A., Kidd, P.S. (2019). Implementing nickel phytomining in a serpentine quarry in NW Spain. Journal of Geochemical Exploration, 197, 1-13. https://doi.org/10.1016/j.gexplo.2018.11.001

Chakrabarty, N. (2015). Arsenic Toxicity: Prevention and Treatment: CRC Press.

Chaney, R. (1983). Plant uptake of inorganic waste constituents.

Chaney, R.L., Angle, J.S., Broadhurst, C.L., Peters, C.A., Tappero, R.V., Sparks, D.L. (2007). Improved understanding of hyperaccumulation yields commercial phytoextraction and phytomining technologies. Journal of Environmental quality, 36(5), 1429-1443. https://doi.org/10.2134/jeq2006.0514

Chaney, R.L., Angle, J.S., McIntosh, M.S., Reeves, R.D., Li, Y.M., Brewer, E.P., Synkowski, E.C. (2005). Using hyperaccumulator plants to phytoextract soil Ni and Cd. Z Naturforsch C, 60(3-4), 190-198.

Chau, Y., Wong, P., Silverberg, B., Luxon, P., Bengert, G. (1976). Methylation of selenium in the aquatic environment. Science, 192(4244), 1130-1131. https://doi.org/10.1126/science.192.4244.1130

Chen, F., Tan, M., Ma, J., Zhang, S., Li, G., Qu, J. (2016). Efficient remediation of PAH-metal co-contaminated soil using microbial-plant combination: A greenhouse study. Journal of Hazardous Materials, 302, 250-261. https://doi.org/10.1016/j.jhazmat.2015.09.068

Chen, R., Zhou, Z., Liu, Y., Jiang, J., Li, Q., Song, H., Xu, H. (2015). Mycoremediation potential and tolerance responses of Oudemansiella radicata in cadmium-pyrene co-contaminated soil. Journal of Soils and Sediments, 15(5), 1083-1093. https://doi.org/10.1007/s11368-015-1093-7

Chen, Y., Han, Y.H., Cao, Y., Zhu, Y.G., Rathinasabapathi, B., Ma, L.Q. (2017). Arsenic transport in rice and biological solutions to reduce arsenic risk from rice. Frontiers in plant science, 8, 268. https://doi.org/10.3389/fpls.2017.00268

Chen, Y., Wang, Y., Wu, W., Lin, Q., Xue, S. (2006). Impacts of chelate-assisted phytoremediation on microbial community composition in the rhizosphere of a copper accumulator and non-accumulator. Science of the total environment, 356(1), 247-255. https://doi.org/10.1016/j.scitotenv.2005.04.028

Chien, M. F., Makita, R., Sugawara, K., Inoue, C. (2015). Study on As Uptake and Rhizobacteria of Two as Hyperaccumulators Forward to As Phytoremediation. Paper presented at the Advanced Materials Research. https://doi.org/10.4028/www.scientific.net/AMR.1130.568

Chunilall, V., Kindness, A., Jonnalagadda, S.B. (2006). Impact of coal mine dump contaminated soils on elemental uptake by Spinacia oleracea (spinach). Journal of Environmental Science and Health Part B, 41(3), 297-307. https://doi.org/10.1080/03601230500357447

Chunilall, V., Kindness, A., Jonnalagadda, S. (2005). Heavy metal uptake by two edible Amaranthus herbs grown on soils contaminated with lead, mercury, cadmium, and nickel. Journal of Envirnomental Science and Health, 40(2), 375-384.https://doi.org/10.1081/pfc-200045573

Cluis, C. (2004). Junk-greedy greens: phytoremediation as a new option for soil decontamination. BioTeach Journal, 2(6), 1-67.

Conesa, H.M., Moradi, A.B., Robinson, B.H., Kühne, G., Lehmann, E., Schulin, R. (2009). Response of native grasses and Cicer arietinum to soil polluted with mining wastes: Implications for the management of land adjacent to mine sites. Environmental and Experimental Botany, 65(2), 198-204. https://doi.org/10.1016/j.envexpbot.2008.09.004

Coniglio, M.S., Busto, V.D., González, P.S., Medina, M.I., Milrad, S., Agostini, E. (2008). Application of Brassica napus hairy root cultures for phenol removal from aqueous solutions. Chemosphere, 72(7), 1035-1042. https://doi.org/10.1016/j.chemosphere.2008.04.003

Cuevas, J., Daliakopoulos, I.N., del Moral, F., Hueso, J.J., Tsanis, I.K. (2019). A review of soil- improving cropping systems for soil salinization. Agronomy, 9(6), 295. https://doi.org/10.3390/agronomy9060295 
Cunningham, S.D., Anderson, T. A., Schwab, A. P., \& Hsu, F. (1996). Phytoremediation of soils contaminated with organic pollutants. Advances in Agronomy, 56(4), 55-114.

Das, P., Datta, R., Sarkar, D. (2012). Nitroreductase enzyme mediated phytodegradation of 2, 4, 6 Trinitrotoluene by vetiver grass. Paper presented at the Agronomy Abstracts.

Debez, A., Belghith, I., Friesen, J., Montzka, C., Elleuche, S. (2017). Facing the challenge of sustainable bioenergy production: Could halophytes be part of the solution?. Journal of biological engineering, 11(1), 27. https://doi.org/10.1186/s13036-017-0069-0

De-Farias, V., Maranho, L.T., de Vasconcelos, E.C., da Silva Carvalho Filho, M.A., Lacerda, L.G., Azevedo, J.A.M., Soccol, C.R. (2009). Phytodegradation potential of Erythrina crista-galli L., Fabaceae, in petroleumcontaminated soil. Applied biochemistry and biotechnology, 157(1), 10-22. https://doi.org/10.1007/s12010$\underline{009-8531-1}$

Dechamps, C., Roosens, N. H., Hotte, C., Meerts, P. (2005). Growth and mineral element composition in two ecotypes of Thlaspi caerulescens on $\mathrm{Cd}$ contaminated soil. Plant and soil, 273(1-2), 327-335. https://doi.org/10.1007/s11104-005-0099-0

Dhillon, K., Dhillon, S., Dogra, R. (2010). Selenium accumulation by forage and grain crops and volatilization from seleniferous soils amended with different organic materials. Chemosphere, 78(5), 548-556. https://doi.org/10.1016/j.chemosphere.2009.11.015

Di Gregorio, S., Barbafieri, M., Lampis, S., Sanangelantoni, A. M., Tassi, E., Vallini, G. (2006). Combined application of Triton X-100 and Sinorhizobium sp. Pb002 inoculum for the improvement of lead phytoextraction by Brassica juncea in EDTA amended soil. Chemosphere, 63(2), 293-299. https://doi.org/10.1016/j.chemosphere.2005.07.020

Di, X., Beesley, L., Zhang, Z., Zhi, S., Jia, Y., Ding, Y. (2019). Microbial Arsenic Methylation in Soil and Uptake and Metabolism of Methylated Arsenic in Plants: A Review. International Journal of Environmental Research and Public Health, 16(24), 5012. https://doi.org/10.3390/ijerph16245012

Dixit, S., Singh, D. (2013). Phycoremediation of lead and cadmium by employing Nostoc muscorum as biosorbent and optimization of its biosorption potential. International Journal of Phytoremediation, 15(8), 801-813. https://doi.org/10.1080/15226514.2012.735290

Domínguez, M.T., Maranón, T., Murillo, J. M., Schulin, R., Robinson, B.H. (2008). Trace element accumulation in woody plants of the Guadiamar Valley, SW Spain: a large-scale phytomanagement case study. Environmental Pollution, 152(1), 50-59. https://doi.org/10.1016/j.envpol.2007.05.021

Dulay, R., Pascual, A., Constante, R., Tiniola, R., Areglo, J., Arenas, M., Moro, L. (2015). Growth response and mycoremediation activity of Coprinus comatus on heavy metal contaminated media. Mycosphere, 6(1), 1-7.

Durand, A., Piutti, S., Rue, M., Morel, J., Echevarria, G., Benizri, E. (2015). Improving nickel phytoextraction by co-cropping hyperaccumulator plants inoculated by plant growth promoting rhizobacteria. Plant and soil, 114. https://doi.org/10.1007/s11104-015-2691-2

Edwards, M.R., Hetu, M.F., Columbus, M., Silva, A., Lefebvre, D.D. (2011). The effect of ethylene glycol on the phytovolatilization of 1, 4-dioxane. International Journal of Phytoremediation, 13(7), 702-716. https://doi.org/10.1080/15226514.2010.525553

Ehsan, S., Ali, S., Noureen, S., Mahmood, K., Farid, M., Ishaque, W., Rizwan, M. (2014). Citric acid assisted phytoremediation of cadmium by Brassica napus L. Ecotoxicology and environmental safety, 106, 164-172. https://doi.org/10.1016/j.ecoenv.2014.03.007

Essien, E., Efeanacho, M., Nwachukwu, G. (2015). The impact of Cow Dung Augmentation for Remediation of Crude Oil Polluted Soil by Eleusine indica. Journal of Applied Sciences and Environmental Management, 19(1), 103-107. https://doi.org/10.4314/jasem.v19i1.14

Farraji.H. (2014). Wastewater Treatment by Phytoremediation Methods. In M. A. H.A.Aziz (Ed.), Wastewater Engineering: Types, Characteristics and Treatment Technologies (pp. 205-218). Malaysia: IJSRPUB.

Farraji, H. (2018). Phytoremediation of Nitrogen and Phosphorus in Municipal Wastewater by Cyperus alternifolius Planted Constructed Wetland. In Handbook of Research on Microbial Tools for Environmental Waste Management (pp. 146-163). IGI Global. https://doi.org/10.4018/978-1-5225-3540-9.ch008

Farraji, H., Zaman, N.Q., Mohajeri, P. (2020). Waste disposal: Sustainable waste treatments and facility siting concerns. In Sustainable Infrastructure: Breakthroughs in Research and Practice (pp. 659-690). IGI Global. https://doi.org/10.4018/978-1-7998-0948-7.ch031

Farraji, H., Aziz, H.A., Tajuddin, R.M., Mojiri, A. (2014). Optimization of Phytoremediation of Lead-Contaminated Soil by Spinach (Spinacia oleracea L). International Journal of Scientific Research in Knowledge, 2(10), 480. http://dx.doi.org/10.12983/ijsrk-2014-p0480-0486 
Farraji, H., Zaman, N.Q., Tajuddin, R., Faraji, H. (2016). Advantages and disadvantages of phytoremediation: A concise review. Int. J. Env. Tech. Sci., 2, 69-75.

Farraji, H., Zaman, N.Q., Vakili, M., Faraji, H. (2016). Overpopulation and Sustainable Waste Management. International Journal of Sustainable Economies Management (IJSEM), 5(3), 13-36. http://dx.doi.org/10.4018/IJSEM.2016070102

Farraji, H., Zaman, N.Q., Zahed, M.A., Faraji, H. (2017). Role of rhizoremediation in decontaminating some hazardous pollutants. In Handbook of Research on Inventive Bioremediation Techniques (pp. 213-246). IGI Global. http://dx.doi.org/10.4018/978-1-5225-2325-3.ch009

Favas, P.J., Pratas, J. (2016). Phytofiltration of $\mathrm{Pb}-, \mathrm{Cu}-$, and $\mathrm{Zn}$-contaminated water by native aquatic plants. International Multidisciplinary Scientific GeoConference: SGEM: Surveying Geology \& mining Ecology Management, 1, 503-508.

Feng, T., Lin, H., Guo, Q., Feng, Y. (2014). Influence of an arsenate-reducing and polycyclic aromatic hydrocarbonsdegrading Pseudomonas isolate on growth and arsenic accumulation in Pteris vittata L. and removal of $\begin{array}{lllll}\text { phenanthrene. International biodeterioration \& biodegradation, } & 94, & \text { 12-18. }\end{array}$ https://doi.org/10.1016/j.ibiod.2014.06.005

Flowers, T.J., Troke, P.F., Yeo, A.R. (1977). The mechanism of salt tolerance in halophytes. Annual review of plant physiology, 28(1), 89-121.

Flowers, T. J. (2015a). eHALOPH a database of salt-tolerant plants: helping put halophytes to work.

Flowers, T.J., Colmer, T.D. (2015b). Plant salt tolerance: adaptations in halophytes. Annals of botany, 115(3), 327331. https://doi.org/10.1093/pcp/pcv155

Franklin, H.M. (2014). The interaction of New Zealand native plants with nitrogen in Canterbury's agricultural landscapes. Lincoln University.

Fu, F., Wang, Q. (2011). Removal of heavy metal ions from wastewaters: a review. Journal of environmental management, 92(3), 407-418. https://doi.org/10.1016/j.jenvman.2010.11.011

Fu, X.Y., Zhu, B., Han, H.J., Zhao, W., Tian, Y.S., Peng, R.H., Yao, Q.H. (2016). Enhancement of naphthalene tolerance in transgenic Arabidopsis plants overexpressing the ferredoxin-like protein (ADI1) from rice. Plant Cell Reports, 35(1), 17-26. https://doi.org/10.1007/s00299-015-1861-2

Ganesan, V. (2008). Rhizoremediation of cadmium soil using a cadmium-resistant plant growth-promoting rhizopseudomonad. Current microbiology, 56(4), 403-407. https://doi.org/10.1007/s00284-008-9099-7

Gangola, S., Pankaj, G.N., Srivastava, A., Sharma, A. (2015). Enhanced Biodegradation of Endosulfan by Aspergillus and Trichoderma spp. Isolated from an Agricultural Field of Tarai Region of Uttarakhand. Pesticide Research Journal, 27(2), 223-230.

Gangola, S., Pankaj, G.N., Khati, P., Sharma, A. (2015) Mycoremediation of Imidaclopridin the Presence of Different Soil Amendments using Trichoderma_longibrachiatum and Aspergillusoryzae Isolated from Pesticide Contaminated Agricultural fields of Uttarakhand. J. Bioremed. Biodeg., 6, 310. http://dx.doi.org/10.4172/2155-6199.1000310

García-Delgado, C., Alfaro-Barta, I., Eymar, E. (2015). Combination of biochar amendment and mycoremediation for polycyclic aromatic hydrocarbons immobilization and biodegradation in creosote-contaminated soil. Journal of Hazardous Materials, 285, 259-266. https://doi.org/10.1016/j.jhazmat.2014.12.002

Ghasemi, Z., Ghaderian, S.M., Rodríguez-Garrido, B., Prieto-Fernández, Á., Kidd, P.S. (2018). Plant speciesspecificity and effects of bioinoculants and fertilization on plant performance for nickel phytomining. Plant and Soil, 425(1-2), 265-285. https://doi.org/10.1007/s11104-017-3553-x

Ghosh, M., Singh, S. (2005). A review on phytoremediation of heavy metals and utilization of it's by products. Asian J Energy Environ, 6(4), 18.

Girling, C.A., Peterson, P.J. (1980). Gold in plants. Gold Bulletin, 13(4), 151-157. https://doi.org/10.1007/BF03215461

Gomes, P.I., Asaeda, T. (2009). Phycoremediation of Chromium (VI) by Nitella and impact of calcium encrustation. Journal of Hazardous Materials, 166(2), 1332-1338. https://doi.org/10.1016/j.jhazmat.2008.12.055

Gonzälez-Oreja, J., Rozas, M., Alkorta, I., Garbisu, C. (2008). Dendroremediation of heavy metal polluted soils. Reviews on environmental health, 23(3), 223-234. https://doi.org/10.1515/REVEH.2008.23.3.223

Gothalwal, R., Chillara, S. (2012). Cyanoremediation: A Green Clean Technology Microorganisms in Environmental Management (pp. 767-786): Springer.https://doi.org/10.1007/978-94-007-2229-3_34

Griboff, J., Wunderlin, D.A., Monferran, M.V. (2018). Phytofiltration of $\mathrm{As}^{3+}$, $\mathrm{As}^{5+}$, and $\mathrm{Hg}$ by the aquatic macrophyte Potamogeton pusillus L, and its potential use in the treatment of wastewater. International journal of phytoremediation, 20(9), 914-921. https://doi.org/10.1080/15226514.2018.1448360 
Gumaelius, L., Lahner, B., Salt, D.E., Banks, J.A. (2004). Arsenic hyperaccumulation in gametophytes of Pteris vittata. A new model system for analysis of arsenic hyperaccumulation. Plant physiology, 136(2), 3198-3208. https://doi.org?10/1104/pp.104.044073

Gurska, J., Wang, W., Gerhardt, K.E., Khalid, A.M., Isherwood, D.M., Huang, X.D., Greenberg, B.M. (2009). Three year field test of a plant growth promoting rhizobacteria enhanced phytoremediation system at a land farm for treatment of hydrocarbon waste. Environmental science \& technology, 43(12), 4472-4479. https://doi.org/10.1021/es801540h

Hakeem, K., Sabir, M., Ozturk, M., Mermut, A.R. (2014). Soil remediation and plants: prospects and challenges: Academic Press.

Hanumantha Rao, P.K., Raghavan, R., Subramanian, B.G., Sivasubramanian, V.V. (2011). Application of phycoremediation technology in the treatment of wastewater from a leather-processing chemical manufacturing facility. Water SA, 37(1), 07-14. https://doi.org/10.4314/wsa.v37i1.64099

Harris, A., Naidoo, K., Nokes, J., Walker, T., Orton, F. (2009). Indicative assessment of the feasibility of Ni and Au phytomining in Australia. Journal of cleaner production, 17(2), 194-200.

Heaton, A.C., Rugh, C.L., Wang, N.j., Meagher, R.B. (1998). Phytoremediation of mercury-and methylmercurypolluted soils using genetically engineered plants. Journal of Soil Contamination,7(4), 497-509. https://doi.org/10.1080/10588339891334384

Hokura, A., Omuma, R., Terada, Y., Kitajima, N., Abe, T., Saito, H., Nakai, I. (2006). Arsenic distribution and speciation in an arsenic hyperaccumulator fern by X-ray spectrometry utilizing a synchrotron radiation source. Journal of Analytical Atomic Spectrometry, 21(3), 321-328.

Houben, D., Evrard, L., Sonnet, P. (2013). Beneficial effects of biochar application to contaminated soils on the bioavailability of $\mathrm{Cd}, \mathrm{Pb}$ and $\mathrm{Zn}$ and the biomass production of rapeseed (Brassica napus L.). biomass and bioenergy, 57, 196-204. https://doi.org/10.1016/j.biombioe.2013.07.019

Huang, Y., Miyauchi, K., Inoue, C., Endo, G. (2016). Development of suitable hydroponics system for phytoremediation of arsenic-contaminated water using an arsenic hyperaccumulator plant Pteris vittata. Bioscience, biotechnology, and biochemistry, 80(3), 614-618. https://doi.org/10.1080/09168451.2015.1107461

Hughes, J. B., Shanks, J., Vanderford, M., Lauritzen, J., Bhadra, R. (1996). Transformation of TNT by aquatic plants and plant tissue cultures. Environmental science \& technology, 31(1), 266-271. https://doi.org/10.1021/es960409h

Hutchinson, S.L., Banks, M., Schwab, A. (2001). Phytoremediation of aged petroleum sludge. Journal of Environmental quality, 30(2), 395-403. https://doi.org/10.2134/jeq2001.302395x

Indraratna, B., Athukorala, R., Vinod, J. (2012). Estimating the rate of erosion of a silty sand treated with lignosulfonate. Journal of Geotechnical and Geoenvironmental Engineering, 139 (5), 701-714.

Janssens, TS., Roelofs, D., Vanstraalen, N. (2009). Molecular mechanisms of heavy metal tolerance and evolution in invertebrates. Insect Science, 16(1), 3. https://doi.org/10.1111/j.1744-7917.2009.00249.x

Jansson, C., Wullschleger, S.D., Kalluri, U.C., Tuskan, G.A. (2010). Phytosequestration: carbon biosequestration by plants and the prospects of genetic engineering. BioScience, 60(9), 685-696. https://doi.org/10.1525/bio.2010.60.9.6

Jasrotia, S., Kansal, A., Kishore, V. (2014). Arsenic phyco-remediation by Cladophora algae and measurement of arsenic speciation and location of active absorption site using electron microscopy. Microchemical journal, 114, 197-202. https://doi.org/10.1016/j.microc.2014.01.005

Jiang, C.A., Wu, Q.T., Goudon, R., Echevarria, G., Morel, J.L. (2015). Biomass and metal yield of co-cropped Alyssum murale and Lupinus albus. Australian Journal of Botany, 63(2), 159-166. https://doi.org/10.1071/BT14261

Joner, E., Leyval, C. (2003). Phytoremediation of organic pollutants using mycorrhizal plants: a new aspect of rhizosphere interactions. Agronomie, 23(5-6), 495-502. 10.1051/agro:2003021

Jones, G.K. (2009). Bioremediation of Contaminated Riparian Zones Using Mycorrhizal Fungi-An Exploration of the Feasibility of Restoration Through Mycoremediation. The Evergreen State College.

Jesus, J.M., Danko, A.S., Fiúza, A., Borges, M.T. (2015). Phytoremediation of salt-affected soils: a review of processes, applicability, and the impact of climate change. Environmental Science and Pollution Research, 22(9), 6511-6525. https://doi.org/10.1007/s11356-015-4205-4

Islam, M.S., Saito, T., Kurasaki, M. (2015). Phytofiltration of arsenic and cadmium by using an aquatic plant, Micranthemum umbrosum: Phytotoxicity, uptake kinetics, and mechanism. Ecotoxicology and environmental safety, 112, 193-200. https://doi.org/10.1016/j.ecoenv.2014.11.006 
Islam, M.S., Sikder, M.T., Kurasaki, M. (2017). Potential of Micranthemum umbrosum for phytofiltration of organic arsenic species from oxic water environment. International journal of environmental science and technology, 14(2), 285-290. https://doi.org/10.1007/s13762-016-1142-9

Islam, M.S., Ueno, Y., Sikder, M.T., Kurasaki, M. (2013). Phytofiltration of arsenic and cadmium from the water environment using Micranthemum umbrosum (JF Gmel) SF Blake as a hyperaccumulator. International journal of phytoremediation, 15(10), 1010-1021. https://doi.org/10.1080/15226514.2012.751356

Jasrotia, S., Kansal, A., Mehra, A. (2017). Performance of aquatic plant species for phytoremediation of arseniccontaminated water. Applied Water Science, 7(2), 889-896. https://doi.org/10.1007/s13201-015-0300-4

Kabata-Pendias, A. (2010). Trace elements in soils and plants: CRC press.

Kagalkar, A.N., Jadhav, M.U., Bapat, V.A., Govindwar, S.P. (2011). Phytodegradation of the triphenylmethane dye Malachite Green mediated by cell suspension cultures of Blumea malcolmii Hook. Bioresource technology, 102(22), 10312-10318. https://doi.org/10.1016/j.biortech.2011.08.101

Kaimi, E., Mukaidani, T., Tamaki, M. (2007). Effect of rhizodegradation in diesel-contaminated soil under different soil conditions. Plant production science, 10(1), 105-111. https://doi.org/10.1626/pps.10.105

Kamal, M., Ghaly, A., Mahmoud, N., Cote, R. (2004). Phytoaccumulation of heavy metals by aquatic plants. Environment International, 29(8), 1029-1039. https://doi.org/10.1016/S0160-4120(03)00091-6

Kaur, P., Sharma, A., Parihar, L. (2015). In vitro study of mycoremediation of cypermethrin-contaminated soils in different regions of Punjab. Annals of Microbiology, 65(4), 1949-1959. https://doi.org/10.1007/s13213-015$\underline{1033-1}$

Khan, I., Aftab, M., Shakir, S., Ali, M., Qayyum, S., Rehman, M. U., Touseef, I. (2019). Mycoremediation of heavy metal $(\mathrm{Cd}$ and $\mathrm{Cr})-$ polluted soil through indigenous metallotolerant fungal isolates. Environmental monitoring and assessment, 191(9), 585. https://doi.org/10.1007/s10661-019-7769-5

Khatisashvili, G., Matchavariani, L., Gakhokidze, R. (2015). Improving Phytoremediation of Soil Polluted with Oil Hydrocarbons in Georgia. Soil Remediation and Plants, 547. https://doi.org/10.1016/B978-0-12-799937$\underline{1.00019-X}$

Kirkham, M. (2006). Cadmium in plants on polluted soils: effects of soil factors, hyperaccumulation, and amendments. Geoderma, 137(1), 19-32. https://doi.org/10.1016/j.geoderma.2006.08.024

Krabbenhoft, D.P., Babiarz, C.L. (1992). The role of groundwater transport in aquatic mercury cycling. Water Resources Research, 28(12), 3119-3128. https://doi.org/10.1029/92WR01766

Kumar, K. S., Ganesan, K., Rao, P. S. (2007). Phycoremediation of heavy metals by the three-color forms of Kappaphycus alvarezii. Journal of Hazardous Materials, 143(1), 590-592. https://doi.org/10.1016/j.jhazmat.2006.09.061

Kumar, P. N., Dushenkov, V., Motto, H., Raskin, I. (1995). Phytoextraction: the use of plants to remove heavy metals from soils. Environmental science \& technology, 29(5), 1232-1238. https://doi.org/10.1021/es00005a014

Kurniawan, T.A., Chan, G.Y., Lo, W.H., Babel, S. (2006). Physico-chemical treatment techniques for wastewater laden with heavy metals. Chemical Engineering Journal, 118(1), 83-98. https://doi.org/10.1016/j.cej.2006.01.015

LaCoste, C., Robinson, B., Brooks, R. (2001). Uptake of thallium by vegetables: Its significance for human health, phytoremediation, and phytomining. Journal of Plant Nutrition, 24(8), 1205-1215. https://doi.org/10.1081/PLN-100106976

LaCoste, C., Robinson, B., Brooks, R., Anderson, C., Chiarucci, A., Leblanc, M. (1999). The phytoremediation potential of thallium-contaminated soils using Iberis and Biscutella species. International Journal of Phytoremediation, 1(4), 327-338. https://doi.org/10.1080/15226519908500023

Langella, F., Grawunder, A., Stark, R., Weist, A., Merten, D., Haferburg, G., Kothe, E. (2014). Microbially assisted phytoremediation approaches for two multi-element contaminated sites. Environmental Science and Pollution Research, 21(11), 6845-6858. https://doi.org/10.1007/s11356-013-2165-0

Langholtz, M., Carter, D.R., Rockwood, D.L., Alavalapati, J.R., Green, A. (2005). Effect of dendroremediation incentives on the profitability of short-rotation woody cropping of Eucalyptus grandis. Forest Policy and Economics, 7(5), 806-817. https://doi.org/10.1016/j.forpol.2005.03.005

Leblanc, M., Petit, D., Deram, A., Robinson, B.H., Brooks, R.R. (1999). The phytomining and environmental significance of hyperaccumulation of thallium by Iberis intermedia from southern France. Economic geology, 94(1), 109-113. https://doi.org/10.2113/gsecongeo.94.1.109

Lewis, B.G., Johnson, C., Delwiche, C. (1966). Release of volatile selenium compounds by plants. Collection procedures and preliminary observations. Journal of Agricultural and Food Chemistry, 14(6), 638-640. $\underline{\text { https://doi.org/10.1021/jf60148a027 }}$ 
Li, Y.M., Chaney, R., Brewer, E., Roseberg, R., Angle, J. S., Baker, A., Nelkin, J. (2003a). Development of a technology for commercial phytoextraction of nickel: economic and technical considerations. Plant and soil, 249(1), 107-115. https://doi.org/10.1023/A:1022527330401

Lin, C.H., Lerch, R.N., Kremer, R.J., Garrett, H.E. (2011). Stimulated rhizodegradation of atrazine by selected plant species. Journal of Environmental quality, 40(4), 1113-1121. https://doi.org/10.2134/jeq2010.0440

Liphadzi, M., Kirkham, M. (2006). Availability and plant uptake of heavy metals in EDTA-assisted phytoremediation of soil and composted biosolids. South African Journal of Botany, 72(3), 391-397. https://doi.org/10.1016/j.sajb.2005.10.010

Liu, H., Wang, H., Ma, Y., Wang, H., Shi, Y. (2016). Role of transpiration and metabolism in translocation and accumulation of cadmium in tobacco plants (Nicotiana tabacum L.). Chemosphere, 144, 1960-1965. https://doi.org/10.1016/j.chemosphere.2015.10.093

Liu, X., Peng, K., Wang, A., Lian, C., Shen, Z. (2010). Cadmium accumulation and distribution in populations of Phytolacca americana L. and the role of transpiration. Chemosphere, 78(9), 1136-1141. https://doi.org/10.1016/j.chemosphere.2009.12.030

Liu, X., Wang, W.X. (2016). Time changes in biomarker responses in two species of oyster transplanted into a metal contaminated estuary. Science of the total environment, 544, 281-290. https://doi.org/10.1016/j.scitotenv.2015.11.120

Lu, H., Zhang, Y., Liu, B., Liu, J., Ye, J., Yan, C. (2011). Rhizodegradation gradients of phenanthrene and pyrene in sediment of mangrove (Kandelia candel (L.) Druce). Journal of Hazardous Materials, 196, 263-269. https://doi.org/10.1016/j.jhazmat.2011.09.031

Lu, Q., He, Z.L., Graetz, D. A., Stoffella, P.J., Yang, X. (2011). Uptake and distribution of metals by water lettuce (Pistia stratiotes L.). Environmental Science and Pollution Research, 18(6), 978-986. https://doi.org/10.1007/s11356-011-0453-0

Ma, L. Q., Komar, K. M., Tu, C., Zhang, W., Cai, Y., Kennelley, E.D. (2001). A fern that hyperaccumulates arsenic. Nature, 409(6820), 579-579. https://doi.org/10.1038/35054664

Manousaki, E., Kalogerakis, N. (2010). Halophytes present new opportunities in phytoremediation of heavy metals and saline soils. Industrial \& Engineering Chemistry Research, 50(2), 656-660. https://doi.org/10.1021/ie100270x

Mangkoedihardjo, S., Ratnawati, R., Alfianti, N. (2008). Phytoremediation of hexavalent chromium polluted soil using Pterocarpus indicus and Jatropha curcas L. World Appl Sci J, 4(3), 338-342.

Mani, D., Kumar, C. (2014). Biotechnological advances in bioremediation of heavy metals contaminated ecosystems: an overview with special reference to phytoremediation. International Journal of Environmental Science and Technology, 11(3), 843-872. https://doi.org/10.1007/s13762-013-0299-8

Mazaheri, H., Piri, K. (2015). Removal of Phenol by A. belladonna L. Hairy Root. International Journal of Phytoremediation, 17(12), 1212-1219. https://doi.org/10.1080/15226514.2015.1045136

McDonald, C., Duncan, H. (1979). Atmospheric levels of trace elements in Glasgow. Atmospheric Environment (1967), 13(3), 413-417. https://doi.org/10.1016/0004-6981(79)90298-1

McGrath, S.P., Zhao, F.J. (2003). Phytoextraction of metals and metalloids from contaminated soils. Current opinion in biotechnology, 14(3), 277-282. https://doi.org/10.1016/S0958-1669(03)00060-0

Meagher, R.B. (2000). Phytoremediation of toxic elemental and organic pollutants. Current opinion in plant biology, 3(2), 153-162. https://doi.org/10.1016/S1369-5266(99)00054-0

Meagher, R.B., Heaton, A.C. (2005). Strategies for the engineered phytoremediation of toxic element pollution: mercury and arsenic. Journal of Industrial Microbiology and Biotechnology, 32(11-12), 502-513. https://doi.org/10.1007/s10295-005-0255-9

Migliore, L., Fiori, M., Spadoni, A., Galli, E. (2012). Biodegradation of oxytetracycline by Pleurotus ostreatus mycelium: a mycoremediation technique. Journal of Hazardous Materials, 215, 227-232. https://doi.org/10.1016/j.jhazmat.2012.02.056

Mishra, I., Arora, N.K. (2019). Rhizoremediation: A Sustainable Approach to Improve the Quality and Productivity of Polluted Soils. In Phyto and Rhizo Remediation (pp. 33-66). Springer, Singapore. https://doi.org/10.1007/978-981-32-9664-0_2

Min, B., Park, H., Jang, Y., Kim, J.J., Kim, K. H., Pangilinan, J., Spatafora, J.W. (2015). Genome sequence of a white rot fungus Schizopora paradoxa KUC8140 for wood decay and mycoremediation. Journal of Biotechnology, 211, 42-43. https://doi.org/10.1016/j.jbiotec.2015.06.426

Mohsenzadeh, F., Nasseri, S., Mesdaghinia, A., Nabizadeh, R., Zafari, D., Khodakaramian, G., Chehregani, A. (2010). Phytoremediation of petroleum-polluted soils: Application of Polygonum aviculare and its root- 
associated (penetrated) fungal strains for bioremediation of petroleum-polluted soils. Ecotoxicology and environmental safety, 73(4), 613-619. https://doi.org/10.1016/j.ecoenv.2009.08.020

Mohajeri, P., bin Selamat, M. R., Aziz, H.A., Vakili, A.H., Farraji, H. (2018). Geoenvironmental behaviour of leadcontaminated clay with sawdust. Environmental Geotechnics, 6(7), 450-459. https://doi.org/10.1680/jenge. 16.00030

Mojiri, A., Ziyang L., Hui, W., Tajuddin, R.M., Ahmad, Z., AbuAmr, S.S., Aziz, H.A., Farraji, H. (2016). Concentrated Landfill Leachate Treatment with a Combined System Including Electro-Ozonation and Composite Adsorbent Augmented Sequencing Batch Reactor Process. Process Safety and Environmental Protection, 111, 253-262. https://doi.org/10.1016/j.psep.2017.07.013

Molla, A.H., Fakhru'l-Razi, A. (2012). Mycoremediation-a prospective environmental friendly technique of bioseparation and dewatering of domestic wastewater sludge. Environmental Science and Pollution Research, 19(5), 1612-1619. https://doi.org/10.1007/s11356-011-0676-0

Moreno, F.N., Anderson, C.W., Stewart, R.B., Robinson, B.H. (2008). Phytofiltration of mercury-contaminated water: volatilisation and plant-accumulation aspects. Environmental and Experimental Botany, 62(1), 78-85. https://doi.org/10.1016/j.envexpbot.2007.07.007

Natarajan, S., Stamps, R.H., Ma, L.Q., Saha, U.K., Hernandez, D., Cai, Y., Zillioux, E.J. (2011). Phytoremediation of arsenic-contaminated groundwater using arsenic hyperaccumulator Pteris vittata L.: Effects of frond harvesting regimes and arsenic levels in refill water. Journal of Hazardous Materials, 185(2), 983-989. https://doi.org/10.1016/j.jhazmat.2010.10.002

Niazy, M. Magdy., (2019). Rhizofiltration of $\mathrm{Cu}$ from wastewater via lettuce (Pistia stratrat) using na-lauryl sulphate surfactant. J. of Appl. Sci., 34 (11) 2019, 317-334.

Nikalje, G.C., Bhaskar, S.D., Yadav, K., Penna, S. (2019). Halophytes: Prospective Plants for Future. In Ecophysiology, Abiotic Stress Responses and Utilization of Halophytes (pp. 221-234). Springer, Singapore. https://doi.org/10.1007/978-981-13-3762-8_10

Njoku, K., Akinola, M., Oboh, B. (2012). Phytoremediation of crude oil polluted soil: effect of cow dung augmentation on the remediation of crude oil polluted soil by Glycine max. J. Appl. Sci. Res., 8 (1), 277-282.

Nogales, R., Benítez, E. (2006). Absorption of zinc and lead by Dittrichia viscosa grown in a contaminated soil amended with olive-derived wastes. Bulletin of environmental contamination and toxicology, 76(3), 538-544. https://doi.org/10.1007/s00128-006-0953-7

Nouri, H., Borujeni, S. C., Nirola, R., Hassanli, A., Beecham, S., Alaghmand, S., Mulcahy, D. (2017). Application of green remediation on soil salinity treatment; a review on halophytoremediation. Process Safety and Environmental Protection, 107, 94-107. https://doi.org/10.1016/j.psep.2017.01.021

Nwoko, C.O. (2013). Trends in phytoremediation of toxic elemental and organic pollutants. African Journal of Biotechnology, 9(37), 6010-6016.

Okparanma, R.N., Ayotamuno, J.M., Davis, D.D., Allagoa, M. (2013). Mycoremediation of polycyclic aromatic hydrocarbons (PAH)-contaminated oil-based drill-cuttings. African Journal of Biotechnology, 10(26), 51495156.

Olguí, E.J. (2003). Phycoremediation: key issues for cost-effective nutrient removal processes. Biotechnology Advances, 22(1), 81-91. https://doi.org/10.1016/S0734-9750(03)00130-7

Olguín, E.J., Sánchez-Galván, G. (2010). Aquatic phytoremediation: novel insights in tropical and subtropical regions. Pure and Applied Chemistry, 82(1), 27-38. https://doi.org/10.1351/PAC-CON-09-02-13

Panta, S., Lane, P., Doyle, R., Hardie, M., Haros, G., Shabala, S. (2016). Halophytes as a Possible Alternative to Desalination Plants: Prospects of Recycling Saline Wastewater During Coal Seam Gas Operations. In Halophytes for Food Security in Dry Lands (pp. 317-329). Academic Press. https://doi.org/10.1016/B978-012-801854-5.00019-4

Park, S., Kim, K. S., Kim, J.-T., Kang, D., Sung, K. (2011). Effects of humic acid on phytodegradation of petroleum hydrocarbons in soil simultaneously contaminated with heavy metals. Journal of environmental sciences, 23(12), 2034-2041. https://doi.org/10.1016/S1001-0742(10)60670-5

Pilon-Smits, E. (2005). Phytoremediation. Annu. Rev. Plant Biol., 56, 15-39.

Pino, N.J., Muñera, L.M., Peñuela, G.A. (2016). Root exudates and plant secondary metabolites of different plants enhance polychlorinated biphenyl degradation by rhizobacteria. Bioremediation Journal, 20(2), 108-116. https://doi.org/10.1080/10889868.2015.1124065

Prajapati, S.K., Kaushik, P., Malik, A., Vijay, V.K. (2013). Phycoremediation and biogas potential of native algal isolates from soil and wastewater. Bioresource technology, 135, 232-238. https://doi.org/10.1016/j.biortech.2012.08.069 
Prosser, J., Woods, R., Horswell, J., Robinson, B. (2015). The potential in-situ antimicrobial ability of Myrtaceae plant species on pathogens in soil. Soil Biology and Biochemistry, 96, 1-3. https://doi.org/10.1016/j.soilbio.2015.12.007

Prosser, J.A. (2011). Manuka (Leptospermum scoparium) as a remediation species for biosolids amended land: a thesis presented in partial fulfillment of the requirements for the degree of Master of Science in Soil Science at Massey University, Manawatu, New Zealand.

Qin, Q., Li, X., Wu, H., Zhang, Y., Feng, Q., Tai, P. (2013). Characterization of cadmium (108 Cd) distribution and accumulation in Tagetes erecta L. seedlings: Effect of split-root and of remove-xylem/phloem. Chemosphere, 93(10), 2284-2288. https://doi.org/10.1016/j.chemosphere.2013.07.084

Rabhi, M., Ferchichi, S., Jouini, J., Hamrouni, M. H., Koyro, H. W., Ranieri, A., ... \& Smaoui, A. (2010). Phytodesalination of a salt-affected soil with the halophyte Sesuvium portulacastrum L. to arrange in advance the requirements for the successful growth of a glycophytic crop. Bioresource technology, 101(17), 68226828. https://doi.org/10.1016/j.biortech.2010.03.097

Rajamani, S., Siripornadulsil, S., Falcao, V., Torres, M., Colepicolo, P., Sayre, R. (2007). Phycoremediation of heavy metals using transgenic microalgae Transgenic microalgae as green cell factories (pp. 99-109): Springer. https://doi.org/10.1007/978-0-387-75532-8_9

Rahman, F., Sugawara, K., Huang, Y., Chien, M.F., Inoue, C. (2018). Arsenic, lead and cadmium removal potential of Pteris multifida from contaminated water and soil. International journal of phytoremediation, 20(12), 11871193. https://doi.org/10.1080/15226514.2017.1375896

Raskin, I., Smith, R.D., Salt, D.E. (1997). Phytoremediation of metals: using plants to remove pollutants from the environment. Current opinion in biotechnology, 8(2), 221-226. https://doi.org/10.1016/S0958-1669(97)80106$\underline{1}$

Reamer, D., Zoller, W. (1980). Selenium biomethylation products from soil and sewage sludge. Science, 208(4443), 500-502. 10.1126/science.208.4443.500

Rees, F., Sterckeman, T., Morel, J.L. (2016). Root development of non-accumulating and hyperaccumulating plants in metal-contaminated soils amended with biochar. Chemosphere, 142, 48-55. https://doi.org/10.1016/j.chemosphere.2015.03.068

Reeves, R. (2006). Hyperaccumulation of trace elements by plants Phytoremediation of metal-contaminated soils (pp. 25-52): Springer, Dordrecht. https://doi.org/10.1007/1-4020-4688-X_2

Reichenauer, T.G., Germida, J.J. (2008). Phytoremediation of organic contaminants in soil and groundwater. ChemSusChem, 1(8-9), 708-717. https://doi.org/10.1002/cssc.200800125

Rezek, J., Macek, T., Mackova, M., Triska, J., Ruzickova, K. (2008). Hydroxy-PCBs, methoxy-PCBs and hydroxymethoxy-PCBs: metabolites of polychlorinated biphenyls formed in vitro by tobacco cells. Environmental science \& technology, 42(15), 5746-5751. https://doi.org/10.1021/es800445h

Rhodes, C.J. (2012). Feeding and healing the world: through regenerative agriculture and permaculture. Science progress, 95(4), 345-446. https://doi.org/10.3184/003685012X13504990668392

Rhodes, C.J. (2014). Mycoremediation (bioremediation with fungi)-growing mushrooms to clean the earth. Chemical Speciation \& Bioavailability, 26(3), 196-198. https://doi.org/10.3184/095422914X14047407349335

Robinson, B., Anderson, C., Dickinson, N. (2015). Phytoextraction: Where's the action? Journal of Geochemical Exploration, 151, 34-40. https://doi.org/10.1016/j.gexplo.2015.01.001

Robinson, B., Brooks, R., Clothier, B. (1999). Soil amendments affecting nickel and cobalt uptake by Berkheya coddii: potential use for phytomining and phytoremediation. Annals of Botany, 84(6), 689-694. https://doi.org/10.1006/anbo.1999.0970

Robinson, B., Fernández, J.E., Madejón, P., Marañón, T., Murillo, J.M., Green, S., Clothier, B. (2003). Phytoextraction: an assessment of biogeochemical and economic viability. Plant and soil, 249(1), 117-125. https://doi.org/10.1023/A:1022586524971

Robinson, B., Duwig, C., Bolan, N., Kannathasan, M., Saravanan, A. (2003). Uptake of arsenic by New Zealand watercress (Lepidium sativum). Science of the total environment, 301(1), 67-73. https://doi.org/10.1016/S0048-9697(02)00294-2

Robinson, B., Mills, T., Green, S., Chancerel, B., Clothier, B., Fung, L., McIvor, I. (2005). Trace element accumulation by poplars and willows used for stock fodder. New Zealand Journal of Agricultural Research, 48(4), 489-497. https://doi.org/10.1080/00288233.2005.9513683

Robinson, B., Schulin, R., Nowack, B., Roulier, S., Menon, M., Clothier, B., Mills, T. (2006). Phytoremediation for the management of metal flux in contaminated sites. Forest Snow and Landscape Research, 80(2), 221-224. 
Robinson, B.H., Leblanc, M., Petit, D., Brooks, R.R., Kirkman, J.H., Gregg, P.E. (1998). The potential of Thlaspi caerulescens for phytoremediation of contaminated soils. Plant and soil, 203(1), 47-56. https://doi.org/10.1023/A:1004328816645

Römkens, P., Bouwman, L., Japenga, J., Draaisma, C. (2002). Potentials and drawbacks of chelate-enhanced phytoremediation of soils. Environmental Pollution, 116(1), 109-121. https://doi.org/10.1016/S02697491(01)00150-6

Rue, M., Vallance, J., Echevarria, G., Rey, P., Benizri, E. (2015). Phytoextraction of nickel and rhizosphere microbial communities under mono-or multispecies hyperaccumulator plant cover in a serpentine soil. Australian Journal of Botany, 63(2), 92-102. https://doi.org/10.1071/BT14249

Rugh, C.L., Senecoff, J.F., Meagher, R.B., Merkle, S.A. (1998). Development of transgenic yellow poplar for mercury phytoremediation. Nature biotechnology, 16(10), 925-928. https://doi.org/10.1038/nbt1098-925

Sahi, S.V., Bryant, N.L., Sharma, N. C., Singh, S.R. (2002). Characterization of a lead hyperaccumulator shrub, Sesbania drummondii. Environmental science \& technology, 36(21), 4676-4680. https://doi.org/10.1021/es020675x

Sakakibara, M., Watanabe, A., Inoue, M., Sano, S., Kaise, T. (2010). Phytoextraction and phytovolatilization of arsenic from As-contaminated soils by Pteris vittata. Paper presented at the Proceedings of the annual international conference on soils, sediments, water energy, 12(1), 26.

Salt, D.E., Blaylock, M., Kumar, N.P., Dushenkov, V., Ensley, B.D., Chet, I., Raskin, I. (1995). Phytoremediation: a novel strategy for the removal of toxic metals from the environment using plants. Nature biotechnology, 13(5), 468-474. https://doi.org/10.1038/nbt0595-468

Sánchez-Galván, G., Monroy, O., Gómez, J., Olguín, E.J. (2008). Assessment of the hyperaccumulating lead capacity of Salvinia minima using bioadsorption and intracellular accumulation factors. Water, Air, and Soil Pollution, 194(1-4), 77-90. https://doi.org/10.1007/s11270-008-9700-5

Sánchez-Galván, G., Olguín, E. (2009). A holistic approach to phytofiltration of heavy metals: recent advances in rhizofiltration, constructed wetlands, lagoons, and bioadsorbent-based systems. Handbook of advanced industrial and hazardous wastes treatment, 389-408.

Sandhi, A., Landberg, T., Greger, M. (2018a). Effect of pH, temperature, and oxygenation on arsenic phytofiltration by aquatic moss (Warnstorfia fluitans). Journal of environmental chemical engineering, 6(4), 3918-3925. https://doi.org/10.1016/j.jece.2018.05.044

Sandhi, A., Landberg, T., \& Greger, M. (2018b). Phytofiltration of arsenic by aquatic moss (Warnstorfia fluitans). Environmental Pollution, 237, 1098-1105. https://doi.org/10.1016/j.envpol.2017.11.038

Šašek, V., Deshmukh, S., Rai, M. (2005). Potential of ligninolytic basidiomycetes to degrade organopollutants. Biodiversity of fungi: their role in human life, 155-184.

Savaş, H. (2016). Consolidation and swell characteristics of dispersive soils stabilized with lime and natural zeolite. Science and Engineering of Composite Materials, 23(6), 589-598. https://doi.org/10.1515/secm-2014-0202

Schoenmuth, B.W., Pestemer, W. (2004a). Dendroremediation of trinitrotoluene (TNT) Part 1: Literature overview and research concept. Environmental Science and Pollution Research, 11(4), 273-278. https://doi.org/10.1007/BF02979637

Schoenmuth, B.W., Pestemer, W. (2004b). Dendroremediation of trinitrotoluene (TNT) Part 2: Fate of radio-labelled TNT in trees. Environmental Science and Pollution Research, 11(5), 331-339. https://doi.org/10.1007/BF02979648

Schwantes, D., Gonçalves Jr, A.C., Schiller, A.D.P., Manfrin, J., Campagnolo, M.A., Somavilla, E. (2019). Pistia stratiotes in the phytoremediation and post-treatment of domestic sewage. International journal of phytoremediation, 21(7), 714-723. https://doi.org/10.1080/15226514.2018.1556591

Schwitzguébel, J.P., Meyer, J., Kidd, P. (2006). Pesticides removal using plants: phytodegradation versus phytostimulation Phytoremediation Rhizoremediation (pp. 179-198): Springer. https://doi.org/10.1007/978-14020-4999-4 13

Shacklette, H.T., Lakin, H.W., Hubert, A.E., Curtin, G.C. (1970). Absorption of gold by plants. Geol. Surv. Bull.(US);(United States), 1314.

Shahandeh, H., Hossner, L.R. (2000). Enhancement of Cr (11l) phytoaccumulation. International Journal of Phytoremediation, 2(3), 269-286. https://doi.org/10.1080/15226510009359037

Singh, H. (2006). Mycoremediation: fungal bioremediation: John Wiley \& Sons.

Singh, M., Pandey, V., Srivastava, A., Vishwakarma, S. (2011). Enzyme Technology and Mycoremediation by White Rot Fungi. Nova Science Publishers, New York (USA), Inc, 2, 157-163. 
Singh, M., Srivastava, P., Verma, P., Kharwar, R., Singh, N., Tripathi, R. (2015). Soil fungi for mycoremediation of arsenic pollution in agriculture soils. Journal of applied microbiology, 119(5), 1278-1290. https://doi.org/10.1111/jam.12948

Singh, S., Melo, J., Eapen, S., D'souza, S. (2006). Phenol removal using Brassica juncea hairy roots: role of inherent peroxidase and $\mathrm{H}_{2} \mathrm{O}_{2}$. Journal of Biotechnology, 123(1), 43-49. https://doi.org/10.1016/j.jbiotec.2005.10.023

Souza, L.A., Piotto, F.A., Nogueirol, R.C., Azevedo, R.A. (2013). Use of non-hyperaccumulator plant species for the phytoextraction of heavy metals using chelating agents. Scientia Agricola, 70(4), 290-295. https://doi.org/10.1590/S0103-90162013000400010

Srivastava, S., Shrivastava, M., Suprasanna, P., D'souza, S.F. (2011). Phytofiltration of arsenic from simulated contaminated water using Hydrilla verticillata in field conditions. Ecological Engineering, 37(11), 1937-1941. https://doi.org/10.1016/j.ecoleng.2011.06.012

Statwick, J., Majestic, B.J., Sher, A.A. (2016). Characterization and benefits of selenium uptake by an Astragalus hyperaccumulator and a non-accumulator. Plant and soil, 1-15. https://doi.org/10.1007/s11104-016-2842-0

Sun, Q., Ye, Z.H., Wang, X.R., Wong, M.H. (2007). Cadmium hyperaccumulation leads to an increase of glutathione rather than phytochelatins in the cadmium hyperaccumulator Sedum alfredii. Journal of plant physiology, 164(11), 1489-1498. https://doi.org/10.1016/j.jplph.2006.10.001

Suresh, B., Sherkhane, P., Kale, S., Eapen, S., Ravishankar, G. (2005). Uptake and degradation of DDT by hairy root cultures of Cichorium intybus and Brassica juncea. Chemosphere, 61(9), 1288-1292. https://doi.org/10.1016/j.chemosphere.2005.03.086

Sut-Lohmann, M., Jonczak, J., Raab, T. (2020). Phytofiltration of chosen metals by aquarium liverwort (Monosoleum $\begin{array}{llll}\text { tenerum). Ecotoxicology and } & \text { environmental }\end{array}$ https://doi.org/10.1016/j.ecoenv.2019.109844

Tarzia, M., De Vivo, B., Somma, R., Ayuso, R., McGill, R., Parrish, R. (2002). Anthropogenic vs. natural pollution: an environmental study of an industrial site under remediation (Naples, Italy). Geochemistry: Exploration, Environment, Analysis, 2(1), 45-56. https://doi.org/10.1144/1467-787302-006

Tayung, K., Barik, B. (2011). Mycoremediation: An Ecological and Evolutionary Perspective. Advances in Applied Research, 3(1), 92-101.

Teng, Y., Li, X., Chen, T., Zhang, M., Wang, X., Li, Z., Luo, Y. (2016). Isolation of the PCB-degrading bacteria Mesorhizobium sp. ZY1 and its combined remediation with Astragalus sinicus L. for contaminated soil. International Journal of Phytoremediation, 18(2), 141-149. https://doi.org/10.1080/15226514.2015.1073667

Terry, N., Zayed, A., Pilon-Smits, E. (1995). Bioremediation of selenium by plant volatilization: American Chemical Society, Washington, DC (United States).

Tognacchini, A., Rosenkranz, T., van der Ent, A., Machinet, G. E., Echevarria, G., \& Puschenreiter, M. (2020). Nickel phytomining from industrial wastes: Growing nickel hyperaccumulator plants on galvanic sludges. Journal of environmental management, 254, 109798. https://doi.org/10.1016/j.jenvman.2019.109798

Tomé, F.V., Rodríguez, P.B., Lozano, J. (2008). Elimination of natural uranium and 226 Ra from contaminated waters by rhizofiltration using Helianthus annuus L. Science of the total environment, 393(2), 351-357. https://doi.org/10.1016/j.scitotenv.2008.01.013

Ueno, D., Iwashita, T., Zhao, F.J., Ma, J.F. (2008). Characterization of Cd translocation and identification of the Cd form in xylem sap of the Cd-hyperaccumulator Arabidopsis halleri. Plant and Cell Physiology, 49(4), 540-548. https://doi.org/10.1093/pcp/pcn026

Unterbrunner, R., Wieshammer, G., Hollender, U., Felderer, B., Wieshammer-Zivkovic, M., Puschenreiter, M., \& Wenzel, W. W. (2007). Plant and fertiliser effects on rhizodegradation of crude oil in two soils with different nutrient status. Plant and soil, 300(1-2), 117-126. https://doi.org/10.1007/s11104-007-9394-2

Uraguchi, S., Mori, S., Kuramata, M., Kawasaki, A., Arao, T., Ishikawa, S. (2009). Root-to-shoot Cd translocation via the xylem is the major process determining shoot and grain cadmium accumulation in rice. Journal of Experimental Botany, 60(9), 2677-2688. https://doi.org/10.1093/jxb/erp119

Vishnoi, S.R., Srivastava, P.N. (2007). Phytoremediation-green for environmental clean. In Proceedings of Taal2007: the 12th World lake conference (Vol. 1016, p. 1021).

Vakili, A. H., bin Selamat, M.R., Aziz, H.B.A., Mojiri, A., Ahmad, Z., Safarzadeh, M. (2017). Treatment of dispersive clay soil by ZELIAC. Geoderma, 285, 270-279. https://doi.org/10.1016/j.geoderma.2016.10.009

Vamerali, T., Bandiera, M., Hartley, W., Carletti, P., Mosca, G., (2011). Assisted phytoremediation of mixed metal (loid)-polluted pyrite waste: effects of foliar and substrate IBA application on fodder radish. Chemosphere, 84(2), 213-219. https://doi.org/10.1016/j.chemosphere.2011.04.052 
Van der Ent, A., Baker, A.J., Reeves, R.D., Chaney, R.L., Anderson, C.W., Meech, J.A., Echevarria, G. (2015). Agromining: farming for metals in the future?. Environmental science \& technology, 49(8), 4773-4780. https://doi.org/10.1021/es506031u

Van der Ent, A., Baker, A.J., Reeves, R.D., Pollard, A.J., Schat, H. (2013a). Hyperaccumulators of metal and metalloid trace elements: facts and fiction. Plant and soil, 362(1-2), 319-334. https://doi.org/10.1007/s11104$\underline{012-1287-3}$

Van der Ent, B., Van Balgooy, Tjoa, A. (2013b). Ultramafic nickel laterites in Indonesia (Sulawesi, Halmahera): mining, nickel hyperaccumulators and opportunities for phytomining. Journal of Geochemical Exploration, 128, 72-79. https://doi.org/10.1016/j.gexplo.2013.01.009

Van Slycken, S., Witters, N., Meiresonne, L., Meers, E., Ruttens, A., Van Peteghem, P., Vangronsveld, J. (2013). Field evaluation of willow under short rotation coppice for phytomanagement of metal-polluted agricultural soils. International Journal of Phytoremediation, 15(7), 677-689. https://doi.org/10.1080/15226514.2012.723070

Vangronsveld, J., Herzig, R., Weyens, N., Boulet, J., Adriaensen, K., Ruttens, A., Nehnevajova, E. (2009). Phytoremediation of contaminated soils and groundwater: lessons from the field. Environmental Science and Pollution Research, 16(7), 765-794. https://doi.org/10.1007/s11356-009-0213-6

Veselý, T., Tlustoš, P., Száková, J. (2011). The use of water lettuce (Pistia stratiotes L.) for rhizofiltration of a highly polluted solution by cadmium and lead. International Journal of Phytoremediation, 13(9), 859-872. https://doi.org/10.1080/15226514.2011.560214

Wallschläger, D., Desai, M.V., Wilken, R.D. (1996). The role of humic substances in the aqueous mobilization of mercury from contaminated floodplain soils. Water, Air, and Soil Pollution, 90(3-4), 507-520. https://doi.org/10.1007/BF00282665

Wang, Y., Zhang, J.X., Ren, H.J., Wang, Y., Pan, H.Y., Zhang, L.Y. (2015). Phytoremediation potentiality of garlic roots for 2, 4-dichlorophenol removal from aqueous solutions. Applied Microbiology and Biotechnology, 99(8), 3629-3637. https://doi.org/10.1007/s00253-014-6277-3

Warneck, P. (1999). Chemistry of the natural atmosphere (Vol. 71): Academic press.

Weatherford, J., Hammond, A., Ratliff, J. (1997). Investigation of the ability of plants found in western Kentucky to hyperaccumulate lead and aluminum from soils. Microchemical journal, 56(1), 93-102. https://doi.org/10.1006/mchj.1996.1439

Witters, N., Mendelsohn, R., Van Passel, S., Van Slycken, S., Weyens, N., Schreurs, E., Vangronsveld, J. (2012). Phytoremediation, a sustainable remediation technology? II: Economic assessment of $\mathrm{CO}_{2}$ abatement through the use of phytoremediation crops for renewable energy production. biomass and bioenergy, 39, 470-477. https://doi.org/10.1016/j.biombioe.2011.11.017

Wu, M., Xu, Y., Ding, W., Li, Y., Xu, H. (2016). Mycoremediation of manganese and phenanthrene by Pleurotus eryngii mycelium enhanced by Tween 80 and saponin. Applied Microbiology and Biotechnology, 100(16), 7249-7261. https://doi.org/10.1007/s00253-016-7551-3

Xiao-jin, Z., Rong-liang, Q., Sui-hong, H., Tian, T., Senthilkumar, P. (2008). Immobilization and re-vegetation of heavy metal polluted soils in Dabao Mountain, Guangdong Province by amendments. China Environmental Science, 28(9), 775-780.

Xiao, T., Guha, J., Boyle, D., Liu, C.Q., Chen, J. (2004). Environmental concerns related to high thallium levels in soils and thallium uptake by plants in southwest Guizhou, China. Science of the total environment, 318(1), 223-244. https://doi.org/10.1016/S0048-9697(03)00448-0

Xue, S., Chen, Y., Reeves, R.D., Baker, A.J., Lin, Q., Fernando, D.R. (2004). Manganese uptake and accumulation by the hyperaccumulator plant Phytolacca acinosa Roxb.(Phytolaccaceae). Environmental Pollution, 131(3), 393-399. https://doi.org/10.1016/j.envpol.2004.03.011

Yadav, B.K., Siebel, M.A., van Bruggen, J.J. (2011). Rhizofiltration of a heavy metal (lead) containing wastewater using the wetland plant Carex pendula. CLEAN-Soil, Air, Water, 39(5), 467-474. https://doi.org/10.1002/clen.201000385

Yang, X., Feng, Y., He, Z., Stoffella, P.J. (2005). Molecular mechanisms of heavy metal hyperaccumulation and phytoremediation. Journal of Trace Elements in Medicine and Biology, 18(4), 339-353. https://doi.org/10.1016/j.jtemb.2005.02.007

Yang, W., Li, D., Li, Z., Zheng, X., Hong, Y., Jiao, Y., Liu, Y. (2019). Comparison of Salix Genotypes for CoPhytofiltration of Iron and Manganese from Simulated Contaminated Groundwater in a Floating Culture System. Groundwater Monitoring \& Remediation, 39(3), 71-77. https://doi.org/10.1111/gwmr.12338 
Farraji et al.

Phytoremediation: green technology for improving aquatic and terrestrial environments

Yang, W., Zhao, F., Ding, Z., Shohag, M.J.I., Wang, Y., Zhang, X., Yang, X. (2018). Screening of 19 Salix clones in effective phytofiltration potentials of manganese, zinc and copper in pilot-scale wetlands. International journal of phytoremediation, 20(13), 1275-1283. https://doi.org/10.1080/15226514.2014.898020

Ye-Tao, T., Teng-Hao-Bo, D., Qi-Hang, W., Shi-Zhong, W., Rong-Liang, Q., Ze-Bin, W., Tong-Bin, C. (2012). Designing cropping systems for metal-contaminated sites: a review. Pedosphere, 22(4), 470-488. https://doi.org/10.1016/S1002-0160(12)60032-0

Yifru, D.D., Nzengung, V.A. (2008). Organic carbon biostimulates rapid rhizodegradation of perchlorate. Environmental toxicology and chemistry, 27(12), 2419-2426. https://doi.org/10.1897/08-008.1

Yin, X.X., Wang, L., Bai, R., Huang, H., Sun, G.X. (2012). Accumulation and transformation of arsenic in the bluegreen alga Synechocysis sp. PCC6803. Water, Air, \& Soil Pollution, 223(3), 1183-1190. https://doi.org/10.1007/s11270-011-0936-0

Zayed, A., Gowthaman, S., Terry, N. (1998). Phytoaccumulation of trace elements by wetland plants: I. Duckweed. Journal of Environmental quality, 27(3), 715-721. https://doi.org/10.2134/jeq1998.00472425002700030032x

Zhang, X., Hu, Y., Liu, Y., Chen, B. (2011). Arsenic uptake, accumulation and phytofiltration by duckweed (Spirodela polyrhiza L.). Journal of environmental sciences, 23(4), 601-606. https://doi.org/10.1016/S1001$\underline{0742(10) 60454-8}$

Zhang, X., Laubie, B., Houzelot, V., Plasari, E., Echevarria, G., Simonnot, M.O. (2016). Increasing purity of ammonium nickel sulfate hexahydrate and production sustainability in a nickel phytomining process. Chemical Engineering Research and Design, 106, 26-32. https://doi.org/10.1016/j.cherd.2015.12.009

Zhao, C., Fu, Q., Song, W., Zhang, D., Ahati, J., Pan, X., Mortuza, M.G. (2015). Calcifying cyanobacterium (Nostoc calcicola) reactor as a promising way to remove cadmium from water. Ecological Engineering, 81, 107-114. https://doi.org/10.1016/j.ecoleng.2015.04.012

Zhu, Y., Zayed, A., Qian, J., De Souza, M., Terry, N. (1999). Phytoaccumulation of trace elements by wetland plants: II. Water hyacinth. Journal of Environmental quality, 28(1), 339-344. https://doi.org/10.2134/jeq1999.00472425002800010042x

Zhu, Z., Yang, X., Wang, K., Huang, H., Zhang, X., Fang, H., He, Z. (2012). Bioremediation of Cd-DDT cocontaminated soil using the Cd-hyperaccumulator Sedum alfredii and DDT-degrading microbes. Journal of Hazardous Materials, 235, 144-151. https://doi.org/10.1016/j.jhazmat.2012.07.033

Zieve, R., Peterson, P. (1981). Factors influencing the volatilization of selenium from soil. Science of the total environment, 19(3), 277-284. https://doi.org/10.1016/0048-9697(81)90022-X 